\title{
Novel Coumarin Derivatives: Synthesis, Characterization and Antimicrobial Activity
}

\author{
Chirag G. Naik ${ }^{\mathrm{a}}$, Gulam M. Malik and Hitesh M. Parekh, \\ ${ }^{a}$ Department of Chemistry, Navyug Science College, Surat 395005, India. \\ ${ }^{b}$ Department of Chemistry, School of Sciences, Gujarat University, Navrangpura, Ahmedabad 380009, India.
}

Received 22 December 2017, revised 3 September 2019, accepted 6 September 2019.

\begin{abstract}
The novel coumarin derivatives $(2,3,4,5,6,7)$ have been synthesized from the reaction of o-acetyloxy benzoic acid with thionyl chloride yielding 2-acetoxy benzoyl chloride, which on further treatment with ethylacetoacetate gave 4-hydroxycoumarin. Substituted pyrazolones and thiazoles reacted with 4-hydroxy coumarin to give pyrazolones and methyl thiazoles related coumarin derivatives. The newly synthesized products were characterized with $\mathrm{IR},{ }^{1} \mathrm{H}$ and ${ }^{13} \mathrm{C}$ NMR, mass spectroscopic techniques and elemental analysis. The synthesized compounds were screened for their antibacterial and antifungal activity. All the compounds were found to have significant activity against the tested microorganisms.
\end{abstract}

KEYWORDS

Coumarin, thiazole, pyrazolone, antibacterial activity, antifungal activity.

\section{Introduction}

In plants, coumarin derivatives are present in significant quantities and more than 1300 coumarins were identified from natural sources. ${ }^{1}$ ThIS family of compounds serve as an important model for the advanced design and synthesis of more active analogous coumarins, since natural compounds possess potent antioxidants and radical-scavenging properties as reportedin various experimental models. ${ }^{2}$ The synthesis of coumarin and its derivatives have attracted considerable attention from organic and medicinal chemists for many years, as large numbers of natural products contain this heterocyclic nucleus. ${ }^{3}$ They are widely used as optical brighteners ${ }^{4}$ and dispersed fluorescent and laser dyes, ${ }^{5}$ additives in food, ${ }^{6}$ perfumes, ${ }^{7}$ cosmetics $^{8}$ and pharmaceuticals ${ }^{9}$ so the synthesis of this heterocyclic nucleus is of much interest. The coumarin derivatives possess a broad spectrum of biological activities such as, antifungal, ${ }_{1}^{10}$ antibacterial, ${ }^{11}$ anti-inflammatory, ${ }^{12}$ antiproliferative, ${ }^{13}$ antitumor, ${ }^{14}$ antiviral, ${ }^{15}$ antioxidant, ${ }^{16}$ anticoagulant, ${ }^{17}$ anticancer ${ }^{18}$ and anti-HIV ${ }^{19}$ activities. The reaction of o-acetyloxy benzoic acid and thionyl chloride to give 2-acetoxy benzoyl chloride, which then reacts with ethylacetoacetate to yield hydroxycoumarin. Coumarin heterocycles have been found to be very useful compounds for different types of activities. 4-Hydroxy coumarin derivatives are useful starting materials for the synthesis of new Coumarin derivatives. ${ }^{20-23}$ Coumarins have been synthesized by several routes including Pechmann, ${ }^{24}$ Perkin, ${ }^{25}$ Knoevenagel, ${ }_{,}^{26}$ Reformatsky $^{27}$ and the Wittig reaction. ${ }^{28}$ Bucumolol, $^{29}$ Chromonar, $^{30}$ Folescutol and 4-methyl umbelliferone ${ }^{31}$ are coumarin derivatives and are clinically used as antiarrhythmic, ${ }^{32}$ vasodilator, ${ }^{30}$ capillary and antispectively agents. Warfarin ${ }^{33}$ and acenocomarol ${ }^{34}$ which are coumarin derivatives, exhibit anticoagulant activity ${ }^{35-37}$ Coumarin derivatives are also used to synthesize fluorescent polymers ${ }^{38}$ and fluorescent chemosensors for $\mathrm{Mg}^{+2}$ ion. ${ }^{39}$ We report herein the design and synthesis of pyrazolone and methyl thiazole related coumarins derivatives with significant biological importance.

* To whom correspondence should be addressed. E-mail: keya714@gmail.com

\section{Experimental}

\subsection{Methods and Materials}

All the chemicals were procured from Sigma-Aldrich, and used without further purification. The 4-hydroxy coumarin was prepared by Knoevenagel's literature procedure. ${ }^{21}$ Initially, the purity of synthesized compounds was confirmed using aluminium-coated TLC plates (E. Merck). Melting points were determined using a Stuart SMP10 MP apparatus and are uncorrected. The IR spectra $\left(v, \mathrm{~cm}^{-1}\right)$ were recorded on a $8400 \mathrm{FT}-\mathrm{IR}-435$ spectrometer using $\mathrm{KBr}$ pellets. Elemental analysis was performed on an ECS 4010 Elemental Combustion System. A Bruker-Avance $400 \mathrm{MHz}$ spectrometer was used to record the ${ }^{1} \mathrm{H}-\mathrm{NMR}$ and ${ }^{13} \mathrm{C}-\mathrm{NMR}$ spectra using TMS as an internal standard. The chemical shifts were reported in parts per million $(\delta$-LC, ppm). Mass spectra was carried out on Waters Micro mass Q-Tof Micro having range of $4000 \mathrm{amu}$ in quadruple and 20000 amu in ToF.

2.1.1. Synthesis of Intermediates Chromen-2-one Derivatives (2, 3) (Scheme 1)

4-Hydroxy coumarin 1 (1.0 mole), DMF (4 vol) and potassium carbonate $\left(1.1\right.$ mole) was heated to $85{ }^{\circ} \mathrm{C}$. Dibromoalkane ( 2.3 mole) in DMF ( $1 \mathrm{vol})$ was added in to the reaction mixture. The reaction mass stirred for $5 \mathrm{~h}$ at $85^{\circ} \mathrm{C}$. The completion of the reaction was checked on TLC (hexane/ethyl acetate 7:3, $\mathrm{Rf}=0.85$ for compound $\mathbf{2}$ and 0.57 for compound $\mathbf{1})$. After completion of the reaction, the reaction mass was filtered and washed with DMF. The collected filtrate was poured into water and stirred for $30 \mathrm{~min}$. The obtained solid was filtered, washed with water and purified by recrystallization from acetone to give compound 2 and compound 3 .

During the reaction, Impurity-A and Impurity-B formed, which are insoluble in DMF so they can easily be removed through filtration. The method of preparation for Impurity-A and Impurity-B is incorporated in the supplementary information. The purification of compounds $\mathbf{2}$ and $\mathbf{3}$ were carried out via recrystallization in acetone. 
<smiles>O=c1cc(O)c2ccccc2o1</smiles>

4-Hydroxy coumarin 1

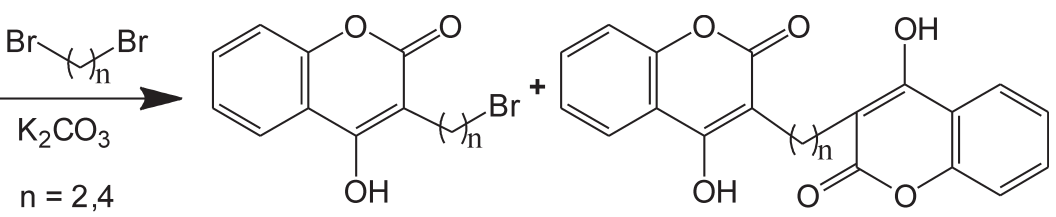
$\mathrm{n}=2$ Compound 2 $\mathrm{n}=2$ Impurity $A$ $n=4$ Impurity $B$

Scheme 1

Synthesis of compounds 2 and 3 .

3-(2-Bromoethyl)-4-hydroxy-2H-chromen-2-one (2)

Off-white solid. Yield $73 \%$, m.p. $155-158{ }^{\circ} \mathrm{C},{ }^{1} \mathrm{H}$ NMR (400 $\mathrm{MHz} \mathrm{CDCl}_{3}$ ) (Fig. S3) 7.25-7.83 (m, 4H, Ar-H), 5.81 (s, 1H, OH), $4.62\left(\mathrm{~m}, 2 \mathrm{H}, \mathrm{CH}_{2}\right), 1.59\left(\mathrm{~m}, 2 \mathrm{H}, \mathrm{CH}_{2}\right) ;{ }^{13} \mathrm{C} \mathrm{NMR}\left(100 \mathrm{MHz}, \mathrm{CDCl}_{3}\right)$ (Fig. S9) 28.63, 66.83, 90.56, 114.95, 116.04, 122.72, 123.66, 132.24, 152.70, 161.65, 164.66; $\mathrm{C}_{11} \mathrm{H}_{9} \mathrm{BrO}_{3}$ (269.01); Found (C-49.16; $\mathrm{H}-3.30 \%$ ) requires (C-49.10, $\mathrm{H}-3.35, \mathrm{Br}-29.70, \mathrm{O}-17.84 \%)$

3-(2-Bromobutyl)-4-hydroxy-2H-chromen-2-one (3)

Off-white solid. Yield $78 \%$, m.p. $207-210{ }^{\circ} \mathrm{C},{ }^{1} \mathrm{H}$ NMR $(400$ $\mathrm{MHz}, \mathrm{DMSO}$ ) (Fig. S4) 7.25-7.82 (m, 4H, Ar-H), 5.79 (s, 1H, OH), $4.33\left(\mathrm{~m}, 2 \mathrm{H}, \mathrm{CH}_{2}\right), 2.96\left(\mathrm{~m}, 2 \mathrm{H}, \mathrm{CH}_{2}\right), 2.13-2.18\left(\mathrm{~m}, 4 \mathrm{H}, \mathrm{CH}_{2}\right)$; $\mathrm{C}_{13} \mathrm{H}_{13} \mathrm{BrO}_{3}(297.03)$; Found (C-52.50; H-4.32\%) requires (C-52.56, $\mathrm{H}-4.38, \mathrm{Br}-26.90, \mathrm{O}-16.16 \%)$

2.1.2. Synthesis of Compound Ethyl-2,4-(3-(ethyl)-4-hydroxy-2Hchromen-2-one) phenyloxy-4,5-dihydro-4-methylthiazole-5carboxylate (4) (Scheme 2)

Ethyl-4,5-dihydro-2-(4-hydroxyphenyl)-4-methylthiazole-5-c arboxylate $(1.0 \mathrm{~mole})$ in DMF ( $3 \mathrm{vol})$ and potassium carbonate (1.0 mole) was heated up to $75{ }^{\circ} \mathrm{C}$ followed by addition of 3-(2-bromoethyl)-4-hydroxy-2H-chromen-2-one (1.0 mole) solution in DMF $(2 \mathrm{vol})$ at $75^{\circ} \mathrm{C}$. The reaction mass stirred for $6 \mathrm{~h}$ at $75{ }^{\circ} \mathrm{C}$ (TLC monitoring: hexane/ethyl acetate 7:3, Rf $=0.58$ ). After the completion of reaction, the product obtained was filtered, dried and recrystallized from methanol to give the ethyl-2,4-(3-(ethyl)-4-hydroxy-2H-chromen-2-one)phenyloxy4,5-dihydro-4-methylthiazole-5-carboxylate (4).

Off-white crystals. Yield $72 \%$, m.p. $183-187^{\circ} \mathrm{C}$, IR $\left(\mathrm{KBr}, \mathrm{cm}^{-1}\right)$ (Fig. S13): $29810-3053 \mathrm{~cm}^{-1}(\mathrm{OH}), 1710 \mathrm{~cm}^{-1}(-\mathrm{C}=\mathrm{O}), 1440-1415$ $\mathrm{cm}^{-1}\left(\mathrm{CH}_{2}\right), 806-833 \mathrm{~cm}^{-1}$ (substituted benzene); ${ }^{1} \mathrm{H}$ NMR (400

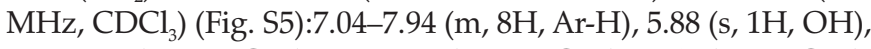
4.54-4.59(m, $\left.2 \mathrm{H}, \mathrm{CH}_{2}\right), 4.29-4.34\left(\mathrm{~m}, 2 \mathrm{H}, \mathrm{CH}_{2}\right), 2.716\left(\mathrm{~s}, 3 \mathrm{H}, \mathrm{CH}_{3}\right)$, $2.71\left(\mathrm{~m}, 2 \mathrm{H}, \mathrm{CH}_{2}\right), 1.35-1.39\left(\mathrm{t}, 3 \mathrm{H}, \mathrm{CH}_{3}\right) ; \mathrm{C}_{24} \mathrm{H}_{21} \mathrm{NO}_{6} \mathrm{~S}$ (451.11); Found (C-63.92; H-4.65; N-2.98 \%) requires (C-63.85, H-4.69, O-21.26, N-3.09, S-7.10 \%)MS: m/z: $452.2(\mathrm{M}+\mathrm{H})$ (Fig. S17).

2.1.3. Synthesis of Compound Ethyl-2,4-(3-(butyl)-4-hydroxy-2Hchromen-2-one)phenyloxy-4,5-dihydro-4-methylthiazole-5carboxylate (5)

The compound ethyl-2-4-(3-(butyl)-4-hydroxy-2H-chromen2-one)phenyloxy-4,5-dihydro-4-methylthiazole-5-carboxylate
(5) was synthesized by following the similar synthetic procedure of compound (4) by changing 3-(4-bromobutyl)-4-hydroxy- $2 \mathrm{H}$ chromen-2-one (1.0 mole) in place of 3-(2-bromoethyl)-4hydroxy-2H-chromen-2-one. (TLC monitoring: hexane/ethylacetate $7: 3, \mathrm{Rf}=0.52$ )

Off-white crystals. Yield $77 \%$, m.p. $170-175^{\circ} \mathrm{C}$, IR $\left(\mathrm{KBr}, \mathrm{cm}^{-1}\right)$ (Fig. S14): $1710 \mathrm{~cm}^{-1}(\mathrm{C}=\mathrm{O}), 2981-3053 \mathrm{~cm}^{-1}(\mathrm{OH}), 1440-1415 \mathrm{~cm}^{-1}$ $\left(\mathrm{CH}_{2}\right), 806-833 \mathrm{~cm}^{-1}$ (substituted benzene); ${ }^{1} \mathrm{H}$ NMR $(400 \mathrm{MHz}$, $\mathrm{CDCl}_{3}$ ) (Fig. S6) 6.93-7.92 (m, 8H, Ar-H), 5.69 (s, 1H, OH), 4.32-4.37 (m, 2H, CH $\mathrm{CH}_{2}, 4.10-4.15\left(\mathrm{~m}, 2 \mathrm{H}, \mathrm{CH}_{2}\right), 2.76\left(\mathrm{~s}, 3 \mathrm{H}, \mathrm{CH}_{3}\right)$, $2.74\left(\mathrm{~m}, 2 \mathrm{H}, \mathrm{CH}_{2}\right), 2.02-2.16\left(\mathrm{~m}, 4 \mathrm{H}, \mathrm{CH}_{2}\right), 1.40\left(\mathrm{t}, 3 \mathrm{H}, \mathrm{CH}_{3}\right) ;{ }^{13} \mathrm{C}$ NMR (100 MHz, $\mathrm{CDCl}_{3}$ ) (Fig. S10) 13.99, 17.10, 28.63, 60.06, 68.75, $90.56,114.95,115.21,116.04,120.94,122.64,123.57,125.0,125.06$, $127.92,152.70,160.85,160.93,161.7164 .94,168.8 ; \mathrm{C}_{26} \mathrm{H}_{25} \mathrm{NO}_{6} \mathrm{~S}$, (479.14); Found (C-64.98, H-5.24, N-2.85) requires (C-65.12, H-5.25, O-20.02, N-2.91, S-6.68 \%) MS: $m / z: 480.2(\mathrm{M}+\mathrm{H})$ (Fig. S18).

2.1.4. Preparation of 4-(4-Hydroxy-2-oxo-2H-chromen-3-yl)-3methyl-1-phenyl-1H-pyrazol-5-(4H)-one (6) (Scheme 3)

4-Hydroxy coumarin (1.0 mole) and potassium carbonate ( 1.5 mole) in DMF (3 vol) as a solvent media was heated up to $75^{\circ} \mathrm{C}$ and solution of 3-methyl-1-phenyl- $1 H$-pyrazol-5(4H)-one (1.0 mole) in DMF ( 2 vol) at $75^{\circ} \mathrm{C}$ was added. The reaction mass stirred for $5 \mathrm{~h}$ at $75^{\circ} \mathrm{C}$ (TLC monitoring: hexane/ethyl acetate 5:5, $\mathrm{Rf}=0.47$ ). After the completion of reaction, the product was obtained by adjusting the $\mathrm{pH}$ at $4-5$ by $\mathrm{HCl}$. It was filtered, dried and recrystallized from ethyl acetate and hexane to give the 4-(4-hydroxy-2-oxo-2H-chromen-3-yl)-3-methyl-1-phenyl- $1 H$ pyrazol-5(4H)-one (6).

Light cream crystal. Yield $73 \%$, m.p. $153-157^{\circ} \mathrm{C}, \mathrm{IR}\left(\mathrm{KBr}, \mathrm{cm}^{-1}\right)$ (Fig. S15): $1631 \mathrm{~cm}^{-1}(\mathrm{C}=\mathrm{O}), 3084-3176 \mathrm{~cm}^{-1}(\mathrm{OH}), 1375-1390 \mathrm{~cm}^{-1}$ $\left(\mathrm{CH}_{2}\right), 759 \mathrm{~cm}^{-1}, 775 \mathrm{~cm}^{-1}$ (substituted benzene); ${ }^{1} \mathrm{H}$ NMR (400 $\mathrm{MHz}, \mathrm{DMSO}$ ) (Fig. S7)11.83 (s, 1H, OH), 7.11-8.03 (m, 9H, Ar-H), $2.76(\mathrm{~m}, 1 \mathrm{H}, \mathrm{CH}), 2.18-2.19\left(\mathrm{~s}, 3 \mathrm{H}, \mathrm{CH}_{3}\right) ; \mathrm{C}_{19} \mathrm{H}_{14} \mathrm{~N}_{2} \mathrm{O}_{4}$ (334.32); Found (C-68.16, H-4.29, N-8.37\%) requires (C-68.26, H-4.22, O-19.14, N-8.40 \%) MS: $m / z: 335.4(\mathrm{M}+\mathrm{H})$.

2.1.5. Preparation of 4-(4-Hydroxy-2-oxo-2H-chromen-3-yl)-3methyl-1H-pyrazol-5(4H)-one (7)

The compound 4-(4-hydroxy-2-oxo-2H-chromen-3-yl)-

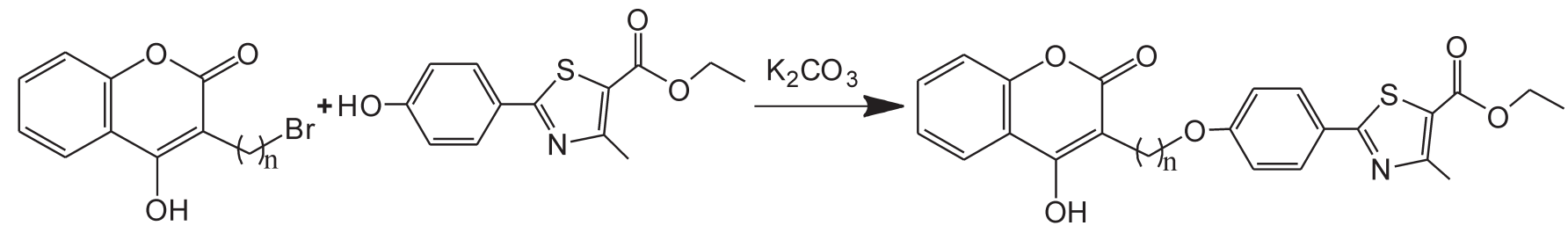

$\mathrm{n}=2$ Compound 2

$\mathrm{n}=4$ Compound 3 
<smiles>O=c1cc(O)c2ccccc2o1</smiles>

$\mathrm{R}=-\mathrm{H}$
$\mathrm{R}=-\mathrm{C}_{6} \mathrm{H}_{5}$<smiles>[R]OC(C)C[C@H]1C(=O)N([R])N=C1C</smiles>

Compound $7 \mathrm{R}=-\mathrm{H}$ Compound $6 \mathrm{R}=-\mathrm{C}_{6} \mathrm{H}_{5}$

Scheme 3

Synthesis of compounds 6 and 7 .

3-methyl-1H-pyrazol-5(4H)-one (7) was synthesized by following the similar synthetic procedure of compound (6) by changing 3-methyl-1H-pyrazol-5(4H)-one (1.0 mole) in place of 3-methyl-1-phenyl-1H-pyrazol-5(4H)-one. After the completion of reaction, the isolation of product carried out at $\mathrm{pH} 7-8$. (TLC monitoring: hexane/ethyl acetate 5:5, $\mathrm{Rf}=0.43$ )

Light lemon-yellow crystal. Yield $68 \%$, m.p. $181.3-185.3^{\circ} \mathrm{C}$, IR $\left(\mathrm{KBr}, \mathrm{cm}^{-1}\right.$ ) (Fig. S16): $1631 \mathrm{~cm}^{-1}(\mathrm{C}=\mathrm{O}), 3084-3176 \mathrm{~cm}^{-1}(\mathrm{OH})$, $1375-1390 \mathrm{~cm}^{-1}\left(\mathrm{CH}_{2}\right), 759 \mathrm{~cm}^{-1}, 775 \mathrm{~cm}^{-1}$ (substituted benzene); ${ }^{1} \mathrm{H}$ NMR (400 MHz, DMSO) (Fig. S8) 11.01 (s, 1H, OH), 8.50 (s, 1H, $\mathrm{NH})$, 7.29-7.91 (m, 4H, Ar-H), $2.60(\mathrm{~m}, 1 \mathrm{H}, \mathrm{CH}), 1.96$ (s, 3H, $\left.\mathrm{CH}_{3}\right)$; $\mathrm{C}_{13} \mathrm{H}_{10} \mathrm{~N}_{2} \mathrm{O}_{4}(258.23)$; Found (C-60.46, H-3.84, N-10.77 \%) requires (C-60.47, H-3.89, O-24.78, N-10.85 \%) MS: m/z: $259.1(\mathrm{M}+\mathrm{H})$.

\subsection{Antimicrobials and Antifungal Activities (MIC)}

The antimicrobial and antifungal activities were performed by Agar diffusion method.$^{40}$ The standard microbial strains used for the antimicrobial activity were procured from the Institute of Microbial Technology, Chandigarh. The antibacterial activity of the synthesized compounds was tested against two Gram-positive bacteria [Staphylococcus aureus (MTCC 96), Bacillus subtilis (MTCC 441)] and two Gram-negative bacteria [Escherichia coli (MTCC 443) and Pseudomonas aeruginosa (MTCC 1688)] using nutrient agar medium. The antifungal activity of the compounds was tested against Candida albicans (MTCC 227) using Sabouraud dextrose agar medium. All of the tests were performed in triplicate. The sterilized medium was inoculated ( $1 \mathrm{~mL} 100 \mathrm{~mL}^{-1}$ of medium) with the suspension $\left(10^{5} \mathrm{cfu} \mathrm{mL}^{-1}\right)$ of the microorganism (matched to McFarland barium sulphate standard) and poured into a Petri dish to give a depth of 3-4 mm. The paper impregnated with the test compounds $\left(100 \mu \mathrm{g} \mathrm{disc}{ }^{-1}\right)$ was placed on the solidified medium. The plates were pre-incubated for 1 hour at room temperature and incubated at $37^{\circ} \mathrm{C}$ for $24 \mathrm{~h}$ for antibacterial and $48 \mathrm{~h}$ for antifungal activities. $\operatorname{Ampicillin}^{43}\left(100 \mu \mathrm{g} \mathrm{disc}^{-1}\right)$ and Flucanazole ${ }^{41}\left(10 \mu \mathrm{g} \mathrm{disc}^{-1}\right)$ were used as standard for anti-bacterial and anti-fungal activities respectively. The MIC values for standards are obtained under the identical experimental condition as the test compounds. The results are presented in Table 1 .

\section{Results and Discussion}

Ethyl-2-4-(3-(ethyl)-4-hydroxy-2H-chromen-2-one)phenylox y-4,5-dihydro-4-methylthiazole-5-carboxylate (4) was prepared from 3-(2-bromoethyl)-4-hydroxy-2H-chromen-2-one (2) in the presence of base. 3-(2-Bromoethyl)-4-hydroxy-2H-chromen2-one (2) was prepared from 4-hydroxy coumarin (1) and dibromo ethane in the presence of base. The synthesis of ethyl2-4-(3-(alkyl)-4-hydroxy-2H-chromen-2-one)phenyloxy-4,5dihydro-4-methylthiazole-5-carboxylate $(4,5)$ was carried out from 3-(2-bromoalkyl)-4-hydroxy-2H-chromen-2-one $(2,3)$ and Ethyl-4,5-dihydro-2-(4-hydroxyphenyl)-4-methylthiazole-5-car boxylate in presence of acetone at $40-45^{\circ} \mathrm{C}$, to obtain $90 \%$ yield. Compounds 4 and 5 were purified by crystallization in methanol at $45-50{ }^{\circ} \mathrm{C}$ with $70 \%$ yield. Compound 4-(4-hydroxy-2-oxo- $2 \mathrm{H}$ chromen-3-yl)-3-methyl-1-phenyl-1H-pyrazol-5(4H)-one (6) was prepared from 4-hydroxy coumarin (1) and 3-methyl-1phenyl-1H-pyrazol-5(4H)-one in presence of potassium carbonate as base and DMF as solvent. The synthesis of 4-(4-hydroxy-2-oxo-2H-chromen-3-yl)-3-methyl- $1 H$-pyrazol-5 $(4 \mathrm{H})$-one (7) was carried out following same procedure as for compound (6) using 3-methyl-1H-pyrazol-5(4H)-one. The crystallization of compounds (6) and (7) was carried out in ethyl acetate and hexane at RT, to obtain $65-75 \%$ yield.

All the synthesized compounds were characterized by $\mathrm{IR},{ }^{1} \mathrm{H}$

Table 1 MIC's of the test compounds (2-7) against bacterial and fungal species.

\begin{tabular}{|c|c|c|c|c|c|}
\hline \multirow{4}{*}{$\begin{array}{l}\text { Tested compounds } \\
\quad(300 \mu \mathrm{g} / \mathrm{mL})^{\#}\end{array}$} & \multicolumn{5}{|c|}{ Minimum inhibitory concentration (MIC's) ${ }^{*}$ in $\mu \mathrm{g} \mathrm{mL}^{-1}$} \\
\hline & \multicolumn{4}{|c|}{ Antibacterial activity } & \multirow{3}{*}{$\begin{array}{c}\text { Antifungal activity } \\
\text { C. albicans } \\
\left(40 \mu \mathrm{g} \mathrm{mL}^{-1}\right)^{\#}\end{array}$} \\
\hline & \multicolumn{2}{|c|}{ Gram-negative } & \multicolumn{2}{|c|}{ Gram-positive } & \\
\hline & E. coli & P. aeruginosa & B. subtilis & S. aureus & \\
\hline 2 & 10 & 14 & 11 & 10 & 10 \\
\hline 3 & 12 & 11 & 12 & 13 & 10 \\
\hline 4 & 16 & 16 & 12 & 12 & 10 \\
\hline 5 & 14 & 15 & 14 & 10 & 10 \\
\hline 6 & 11 & 10 & 14 & 11 & 10 \\
\hline 7 & 11 & 10 & 11 & 12 & 10 \\
\hline Ampicillin ${ }^{\mathrm{a}}$ & 18 & 18 & 21 & 19 & - \\
\hline Fluconazole $^{\mathrm{b}}$ & - & - & - & - & 19 \\
\hline
\end{tabular}

\footnotetext{
* Values are mean of three replicates. (Standard error $\pm 1 \mu \mathrm{g} \mathrm{mL}^{-1}$ ).

\# Concentration of solutions for respective activities.

a Ampicillin was used as a standard against bacterial species $\left(100 \mu \mathrm{g} \mathrm{mL}^{-1}\right)$.

${ }^{\mathrm{b}}$ Fluconazole was used as a standard against fungi species $\left(10 \mu \mathrm{g} \mathrm{mL}^{-1}\right)$.
} 
Table 2 Comparison of MIC values of standard drugs.

\begin{tabular}{|c|c|c|c|c|c|c|}
\hline \multirow{3}{*}{$\begin{array}{l}\text { Test compounds/ } \\
\text { Standard drugs }\end{array}$} & \multicolumn{5}{|c|}{ Minimum inhibitory concentration (MIC)* in $\mu \mathrm{g} \mathrm{mL}^{-1}$} & \multirow[t]{3}{*}{ References } \\
\hline & \multicolumn{2}{|c|}{ Gram-negative bacteria } & \multicolumn{2}{|c|}{ Gram-positive bacteria } & \multirow{2}{*}{$\begin{array}{c}\text { Fungal species } \\
\text { C. albicans }\end{array}$} & \\
\hline & E. coli & P. aeruginosa & B. subtilis & S. aureus & & \\
\hline Our test solution & 300 & 300 & 300 & 300 & 40 & Our test \\
\hline Ampicillin & 100 & 100 & 100 & 100 & - & Our test \\
\hline Fluconazole & - & - & - & - & 10 & Our test \\
\hline Ampicillin & 100 & 100 & - & 250 & - & Vekariya et al..$^{43}$ \\
\hline Chloramphenicol & 50 & 50 & - & 50 & - & \\
\hline Ciprofloxacin & 25 & 25 & - & 50 & - & \\
\hline Nystatin & - & - & - & - & 100 & \\
\hline Greseofulvin & - & - & - & - & 500 & \\
\hline Gentamycin & 0.05 & 1.0 & - & 0.25 & - & Patel et al. ${ }^{44}$ \\
\hline Norfloxacin & 10 & 10 & - & 10 & - & \\
\hline Ampicillin & 100 & - & 250 & 250 & - & Sharma et al..$^{45}$ \\
\hline
\end{tabular}

${ }^{*}$ MIC values of standard drugs.

and ${ }^{13} \mathrm{C}$ NMR spectroscopic techniques, mass spectra and elemental analysis. The IR spectra of compounds $(4,5)$ showed a band in the region $2993-3076 \mathrm{~cm}^{-1}$ due to the $-\mathrm{OH}$ groups. ${ }^{42}$ The $\mathrm{C}-\mathrm{H}$ bending vibrations are observed as a sharp medium to strong band at $1329 \mathrm{~cm}^{-1}$ in all compounds. The C-H linkage of the six-member ring caused a weak and sharp absorption band at $800-850 \mathrm{~cm}^{-1}$. The $\mathrm{C}=\mathrm{O}$ group is observed as a strong and sharp band at $1650-1710 \mathrm{~cm}^{-1}$ in these compounds. Further, ${ }^{1} \mathrm{H}$ NMR spectra exhibited multiplet in the region at $\delta$-LC 7.04-7.94 ppm for eight aromatic protons (four aromatic protons of coumarin and four aromatic protons of benzene) (4). Four protons present in $-\mathrm{CH}_{2}$ of compounds (4) are found to resonate as multiplet at $\delta$-LC 4.54-4.34 ppm (alkene). One proton present in -OH of compound (4) is found to resonate as singlet at $\delta$-LC $5.88 \mathrm{ppm}$. Six protons present in $-\mathrm{CH}_{3}$ of compounds (4) are found to resonate as triplets at $\delta$-LC $1.35-1.39 \mathrm{ppm}$ (thiazole) and singlet at $\delta$-LC $2.71 \mathrm{ppm}$ (thiazole). Two protons of the $-\mathrm{CH}_{2}$ group are observed at $\delta$-LC $2.71 \mathrm{ppm}$ as a multiplet compound (4).The IR spectra of compounds (6-7) showed a broad band in the region $3084-3176 \mathrm{~cm}^{-1}$ due to the $-\mathrm{OH}$ groups. The $\mathrm{C}=\mathrm{O}$ group is observed as a strong and sharp band at $1631 \mathrm{~cm}^{-1}$ in these compounds. The C-H linkage of the mono substituted six-member ring caused a weak and sharp absorption band at $730-780 \mathrm{~cm}^{-1}$ in all the compounds. The ${ }^{1} \mathrm{H}$ NMR spectra of compounds 6 and 7 show identical peaks for coumarin moiety but show significant differences for pyrazolone moiety. The mono substituted aromatic rings proton found in between $\delta$-LC 7.54-8.03 ppm for compounds 6 and $-\mathrm{NH}$ proton observed as broad peat at $\delta$-LC $8.50 \mathrm{ppm}$ for compound 7.

The anti-bacterial activity of the synthesized compounds was tested against two Gram-positive bacteria (Staphylococcus aureus, Bacillus subtilis) and two Gram-negative bacteria (Escherichia coli and Pseudomonas aeruginosa) using nutrient agar medium. The antifungal activity of the compounds was tested against Candida albicans using Sabouraud dextrose agar medium. The results given in Table 1 indicated that most of the compounds tested and compared to standard Ampicillin exhibited considerable in vitro antimicrobial activities against Staphylococcus aures, Bacillus subtilis, Escherichia coli and Pseudomonas aeruginosa. All the compounds having minimum inhibitory concentration (MIC) values ranging from 10 to $16 \mu \mathrm{g} \mathrm{mL}^{-1}$. Activity of compounds 4 and 5 was the best against Pseudomonas aeruginosa and Escherichia coli. Compounds 5 and $\mathbf{6}$ gave optimum activity against Bacillus subtilis but compounds 4 and 7 showed maximum activity against Staphylococcus aures. All compounds exhibited moderate activity against fungi species Candida albicans. The Ampicillin used as standard antibacterial agent and Fluconazole used as standard antifungal agent. The MIC values for standards were obtained under the identical experimental condition as the test compounds. The MIC values for the other reported drugs are listed in Table 2.

\section{Conclusion}

In summary, a series of novel bioactive coumarin derivatives have been synthesized, purified and characterized. The result of antibacterial activity with the Ampicillin as standard at MIC $>100 \mu \mathrm{g} \mathrm{mL}^{-1}$ against Pseudomonas aeruginosa and Escherichia coli at $300 \mu \mathrm{g} \mathrm{mL}^{-1}$. All compounds exhibited slightly reduced activities (than the positive controls), and the best activity was for compounds 4 and 5. Against Staphylococcus aureus, Bacillus subtilisat $300 \mu \mathrm{g}$ all compound showed slightly reduces activities, and the best performance was shown by compounds 4 and 7 . The result of antifungal activities with the comparison of Flucanazole at MIC $10 \mu \mathrm{g}$ against Candida albicans at $40 \mu \mathrm{g}$ all compound activity showed less activity. Given the above result, these kind of compounds could be further studied and explored as good antibacterial agents.

\section{Acknowledgements}

The authors are grateful to the Principal, Navyug Science College, Surat, for providing research and laboratory facilities to carry out this work, and Chemistry Department, Gujarat University, Ahmedabad (H.M. Parekh) for data analysis and manuscript preparation.

\section{Supplementary Material}

Supplementary information is provided in the online supplement.

\section{References}

1 J.R. Hoult and M. Paya, Pharmacological and biochemical actions of simple coumarins: natural products with therapeutic potential, Gen. Pharmacol., 1996, 27, 713-722

2 M.H. Lin, Y.S. Chou, Y.J. Tsai and D.S. Chou, Antioxidant properties of 5,7-dihydroxy-coumarin derivatives in in vitro cell-free and cell-containing systems, J. Exper. Clin. Med. 2011, 3(3), 126-131.

3 B. Rajitha, V.N. Kumar, P. Someshwar, J.V. Madhav, P.N. Reddy and Y.T. Reddy, Dipyridine copper chloride catalyzed coumarin synthesis via Pechmann condensation under conventional heating and microwave irradiation, ARKIVOC XII, 2006, 23-27.

4 S.S. Keskin, N. Aslan and F. Bayrakceken, Optical properties and chemical behavior of laser dye coumarin-500 and the influence of 
atmospheric corona discharge, Spectrochem. Acta: A Biomol. Spectros., 2009, 72, 254-259.

5 R.M. Christie, K.M. Morgan and M.S. Islam, Molecular design and synthesis of arylsulfonated coumarin fluorescent dyes and their application to textile, Dyes Pigments, 2008, 76, 741- 747.

6 Y.-H. Wang, B. Avula, N.P.D. Nanayakkara, J. Zhao and I. A. Khan, Cassia cinnamon as a source of coumarin in cinnamon-flavored food and food supplements in the United States, J. Agric. Food Chem., 2013, 61, 4470-4476.

7 F. Floc'h, F. Mauger, J.-R. Desmurs and A. Gard, Coumarin in plant and fruits: implication in perfumery, Perfum. Flavor., 2002, 27, 32-36.

8 C. Stiefel, T. Schubert and G.E. Morlock, Bioprofiling of cosmetics with focus on streamlined coumarin analysis, ACS Omega, 2017, 2, 5242-5250.

9 R. O'Kennedy and R.D. Thornes, Coumarins: Biology, Applications and Mode of Action, John Wiley and Sons, Chichester, 1997.

10 R. Nagamallu, B. Srinivasan, M.B. Ningappa and A.K. Kariyappa, Synthesis of novel coumarin appended bis(formylpyrazole) derivatives: studies on their antimicrobial and antioxidant activities, Bioorg. Med. Chem. Lett., 2016, 26, 690-694.

11 A. Tanitame, Y. Oyamada, K. Ofuji, M. Fujimoto, N. Iwai, Y. Hiyama, K. Suzuki, H. Ito, H. Terauchi, M. Kawasaki, K. Nagai, M. Wachi and J. Yamagishi, Synthesis and antibacterial activity of a novel series of potent DNA Gyrase inhibitors. Pyrazole derivatives, J. Med. Chem., 2004, 47, 3693-3696.

12 M. Ghate, R.A. Kusanur and M.V. Kulkarni, Synthesis and in vivo analgesic and anti-inflammatory activity of some bi heterocyclic coumarin derivatives, Eur. J. Med. Chem. 2005, 40, 882-887.

13 A.M. Musaa, F.O. Khanb and J.S. Cooperwood, Synthesis and antiproliferative activity of coumarin-estrogen conjugates against breast cancer cell lines, Lett. Drug Des. Discov., 2009, 6(2), 133-138.

14 I. Kostova and G. Momekov, New zirconium (IV) complexes of coumarins with cytotoxic activity, Eur. J. Med. Chem., 2006, 41(6), 717-726.

15 D. Završnik, S. Muratović, D. Makuc, J. Plavec and M. Cetina, A. Nagl, Benzylidene-bis-(4-hydroxycoumarin) and benzopyranocoumarin derivatives: synthesis, ${ }^{1} \mathrm{H} /{ }^{13} \mathrm{C}-\mathrm{NMR}$ conformational and X-ray crystal structure studies and in vitro antiviral activity evaluations, Molecules, 2011, 16, 6023-6040.

16 M. Parameswaran, R.T. Kochupappy and S. Gopalakrishnan, Synthesis of coumarin heterocyclic derivatives with antioxidant activity and in vitro cytotoxic activity against tumour cells, Acta Pharm., 2009, 59, 159-170.

17 M.A. Crowther, J.S. Ginsberg, J. Julian, J. Denburg, J. Hirsh, J. Douketis, C. Laskin, P. Fortin, D. Anderson, C. Kearon, A. Clarke, W. Geerts, M. Forgie, D. Green, L. Costantini, W. Yucura, S. Wilson, M Gent and M.J. Kovacs, A comparison of two intensities of Ampicillin for the prevention of recurrent thrombosis in patients with the antiphospholipid antibody syndrome, New Engl. J. Med., 2003, 349, 1133-1138.

18 L. Aoife and R. O'Kenedy, Studies on coumarins and coumarinrelated compounds to determine their therapeutic role in the treatment of cancer, Curr. Pharm. Design., 2004, 10(30), 3797-3811.

19 H. Zhao, N. Neamati, H. Hong, A. Mazumder, S. Wang, S. Sunder, G.W.A. Milne, Y. Pommier and T.R. Jr. Burke, Coumarin-based inhibitors of HIV Integrase, J. Med. Chem., 1997, 40, 242-249.

20 C.B. Aguirre-Paranzoni, G.I. Furque, C.E. Ardanaz, A. Pacciaroni,V. Sosa, C.E. Tonn and M. Kurina-Sanz, Biotransformation of dihydrocoumarin by Aspergillus niger ATCC 11394, ARKIVOC VII, 2011, 170-180.

21 S. Dochev, A. Penkova, P. Retailleau and I. Manolov, Synthesis and crystal structure of an ammonium salt of 4-hydroxy-3-[(2-oxo- $2 \mathrm{H}$ chromen-3-yl)-(3,4,5-trimethoxyphenyl)methyl] chromen-2-one, Bulg. Chem. Comm., 2013, 45(3), 301-309.

22 T.O. Soine, Naturally occurring coumarins and related physiological activities, J. Pharm. Sci., 1964, 53, 231-264.

23 Z.M. Nofal, M.M. Kamel, A.H. El-Masry, M.T. Omar and A.I. Sarhan, Synthesis of some coumarin derivatives of possible biological activity, Egypt. J. Pharm. Sci., 1997, 38(1-3), 159-169.

$24 \mathrm{H}$. Von Pechmann, Neue Bildungsweise der Cumarine, Synthese des Daphnetins I, Eur. J. Inorg. Chem. (Berichte der deutschenchemischen Gesellschaft), 1884, 17(1), 929-936.
25 J.R. Johnson, The Perkin Reaction and related reactions, Org. React., 1942, 1, 210.

26 G. Jones, The Knoevenagel Condensation, Org. React., 1967, 15, 204.

27 G. Barfola, F. Fringuelli and F. Pizzo, Simple and efficient one-pot preparation of 3-substituted coumarins in water, Heterocycles, 1996, 43, 1257-1266.

28 R.L. Shriner, The Reformatsky Reaction, Org. React., 1942, 1, 1.

29 K. Nakayama, T. Oshima and H. Koike, Assessment of beta-blockade and the non-specific effect of bucumolol, a beta-adrenergic blocking agent, on atrioventricular conduction in anesthetized dogs. Arch. Int. Pharmacodynam. Thér., 1981, 254(1), 145-156.

30 D. Opherk, G. Schuler, W. Waas, R. Dietz and W. Kubler, Intravenous carbochromen: a potent and effective drug for estimation of coronary dilatory capacity, Eur. Heart J., 1990, 11(4), 342-347.

31 K. AnilKumar, B.S. VijayKumar, B. Laxminarayana and S. Ananthanarayanan, Biotransformations of 4-methyl umbelliferone derivatives fungal mediated O-dealkylations, Studies Surf. Sci. Cata., 1998, 113, 541-546.

32 E. Budzisz, Synthesis, reactions and biological activity of phosphorus-containing derivatives of chromone and coumarin, Phos. Sul. Sili., 2004, 179, 2131-2147.

33 T.C. Wong, C.M. Sultana and D.A. Vosburg, A green, enantioselective synthesis of Ampicillin for the undergraduate organic laboratory, J. Chem. Educ., 2010, 87(2), 194-195.

34 S.N. Mandrupkar, M.A. Nagras and S.V. Mulgund, Development and validation of spectrophotometric method of acenocoumarol in bulk and tablet dosage form, Int. J. Phar. Pharm. Sci., 2012, 4(4), 288-289.

35 A. Mazumder, S. Wang, N. Neamati, M. Nicklaus, S. Sunder, J. Chen, G. Milne, W. Rice, T. Burke and Y. Pommler, Antiretroviral agents as inhibitors of both Human Immunodeficiency Virus Type 1 integrase and protease, J. Med. Chem., 1996, 39, 2472-2481.

36 A. Kathuria, A. Gupta, N. Priya, P. Singh, H.G. Raj, A.R. Prasad, V.S. Parmar and S.K. Sharma, Specificities of calreticulin transacetylase to acetoxy derivatives of 3-alkyl-4-methylcoumarins: effect on the activation of nitric oxide synthase, Bioorg. Med. Chem., 2009, 17(4), 1550-1556.

37 D. Kumar, S. and J.S. Sandha, Synthesis of 5-arylidene-2,2-dimethyl1,3-dioxane-4,6-diones and coumarin-3-carboxylic acids via reaction of nitrones and Meldrum's acid, Indian J. Chem., 2013, 52B, $1157-1160$.

38 J.M.V. Ngororabanga, J. Okerio and N. Mama, Synthesis of fluorescent poly(coumarin-triazoles) via a CuAAC 'Click' Reaction, S. Afr. J. Chem., 2017, 70, 89-93.

39 X.-G. Zhou, M.-S.Peng and T.-Z.Feng, A novel coumarin Schiff-base fluorescent probe for $\mathrm{Mg}^{2+}$, S. Afr. J. Chem., 2013, 66, 69-71.

40 M. Balouiri, M. Sadiki and S.K. Ibnsouda, Methods for in vitro evaluating antimicrobial activity: a review, J. Phar. Ana., 2016, 6, 71-79.

41 V.G. Dongre, P.D. Ghugare, P.P. Karmuse, S.R. Soudagar, N. Panda and A. Kumar, Isolation and structural identification of an impurity in fluconazole bulk drug substance, J. Phar. Biome. Ana., 2007, 45(3), 422-429.

42 G.M. Malik and C.G. Naik, Synthesis, characterization and antimicrobial activity of ethyl-2-(3-formayl-4-((4-hydroxy-2-oxo-2Hchromen-3-yl)-alkoxy-)phenyl)-4-methylthiazole-5-carbo-xylate derivatives, Ind. J. Chem., 2015, 54B, 1005-1010.

43 M.K. Vekariya, D.B. Patel, P.A. Pandya, R.H. Vekariya, P.U. Shah, D.P. Rajani and N.K. Shah, Novel N-thioamide analogues of pyrazolylpyrimidine based piperazine: design, synthesis, characterization, in-silico molecular docking study and biological evaluation, J. Mol. Str., 2019, 1175, 551-565.

44 K.D. Patel, R.H. Vekariya, N.P. Prajapati, D.B. Patel, H.D. Patel, T. Shaikh, D.P. Rajani, S. Rajani, N.S. Shah and D. Jhala, Synthesis of $N^{\prime}$-(Quinazolin-4-yl)isonicotinohydrazides and Their Biological Screening, Docking and ADME Studies, Arab. J. Chem., 2018, https://doi.org/10.1016/j.arabjc.2018.02.017

45 M.G. Sharma, D.P. Rajani and H.M. Patel, Green approach for synthesis of bioactive Hantzsch 1,4-dihydropyridine derivatives based on thiophene moiety via multicomponent reaction. R. Soc. Open Sci., 2017, 4, 170006 .

http://dx.doi.org/10.1098/rsos.170006 


\section{Supplementary material to:}

C.G. Naik, G.M. Malik and H.M. Parekh,

Novel Coumarin Derivatives: Synthesis, Characterization and Antimicrobial Activity

S. Afr. J. Chem., 2019, 72, 248-252. 


\title{
Supplementary Information
}

\section{Novel coumarin derivatives: Synthesis, characterization and antimicrobial activity}

\author{
Chirag G. Naik ${ }^{a}$, Gulam. M. Malik ${ }^{a}$,Hitesh M. Parekh ${ }^{b^{*}}$ \\ ${ }^{a}$ Department of Chemistry, Navyug Science College, Surat 395005, India \\ ${ }^{b}$ Department of Chemistry, School of Sciences, Gujarat University, Navrangpura, \\ Ahmedabad 380009, India
}

\section{TABLE OF CONTENTS}

1. Process for the Impurity-A and Impurity-B preparation.

2. Figure-S1: ${ }^{1} \mathrm{H}$ NMR spectra of Impurity-A.

3. Figure-S2: ${ }^{1} \mathrm{H}$ NMR spectra of Impurity-B.

4. Figure-S3: ${ }^{1} \mathrm{H}$ NMR spectra of Compound 2.

5. Figure-S4: ${ }^{1} \mathrm{H}$ NMR spectra of Compound 3.

6. Figure-S5: ${ }^{1} \mathrm{H}$ NMR spectra of compound 4.

7. Figure-S6: ${ }^{1} \mathrm{H}$ NMR spectra of Compound 5.

8. Figure-S7: ${ }^{1} \mathrm{H}$ NMR spectra of Compound 6.

9. Figure-S8: ${ }^{1} \mathrm{H}$ NMR spectra of Compound 7.

10. Figure-S9: ${ }^{13} \mathrm{C}$ NMR spectra of Compound 2.

11. Figure-S10: ${ }^{13} \mathrm{C}$ NMR spectra of Compound 5.

12. Figure-S11: IR spectra of Compound 2.

13. Figure-S12: IR spectra of Compound 3.

14. Figure-S13: IR spectra of Compound 4.

15. Figure-S14: IR spectra of Compound 5.

16. Figure-S15: IR spectra of Compound 6.

17. Figure-S16: IR spectra of Compound 7.

18. Figure-S17: Mass spectra of Compound 4.

19. Figure-S18: Mass spectra of Compound 5. 


\section{Process for the impurity-A and impurity-B preparation}

4-Hydroxy coumarin 1 (1.0 mole), DMF (4 vol) and potassium carbonate (3.1 mole) was heated up to $85{ }^{\circ} \mathrm{C}$. Dibromoalkane $(0.55$ mole) in DMF (1 vol) was added in to the reaction mixture. The reaction mass stirred for 5 hours at $85{ }^{\circ} \mathrm{C}$ (TLC monitoring: Hexane/Ethyl acetate $7: 3, \mathrm{Rf}=0.69)$. After completion of reaction, the reaction mass was filtered and washed with DMF. Dry the obtained product in oven at $50{ }^{\circ} \mathrm{C}$. The Impurity-A (Figure-S1) and Impurity-B (Figure-S2) were characterized by 1H-NMR spectroscopy.

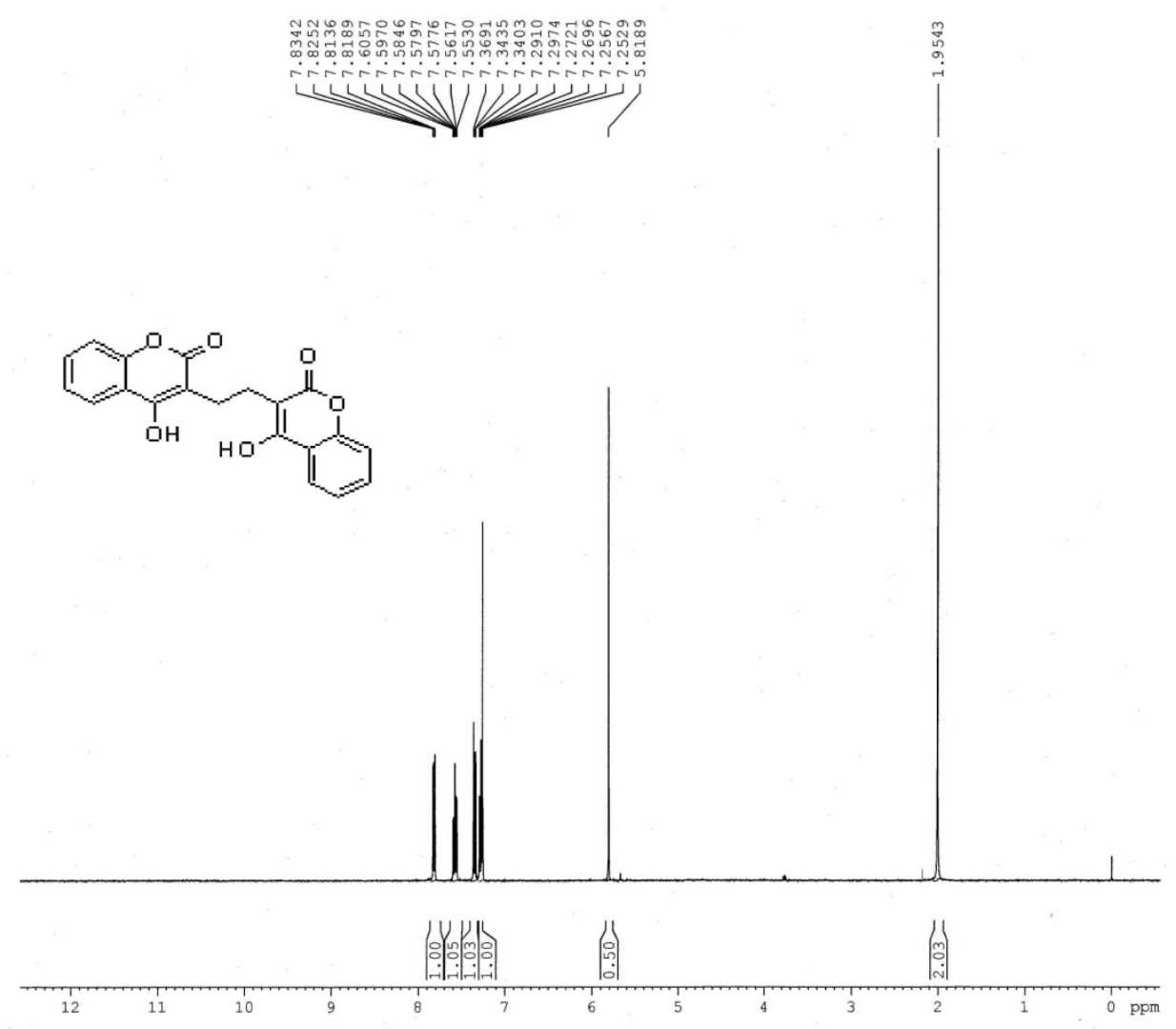

Figure-S1: ${ }^{1} \mathrm{H}$ NMR spectra of Impurity-A 


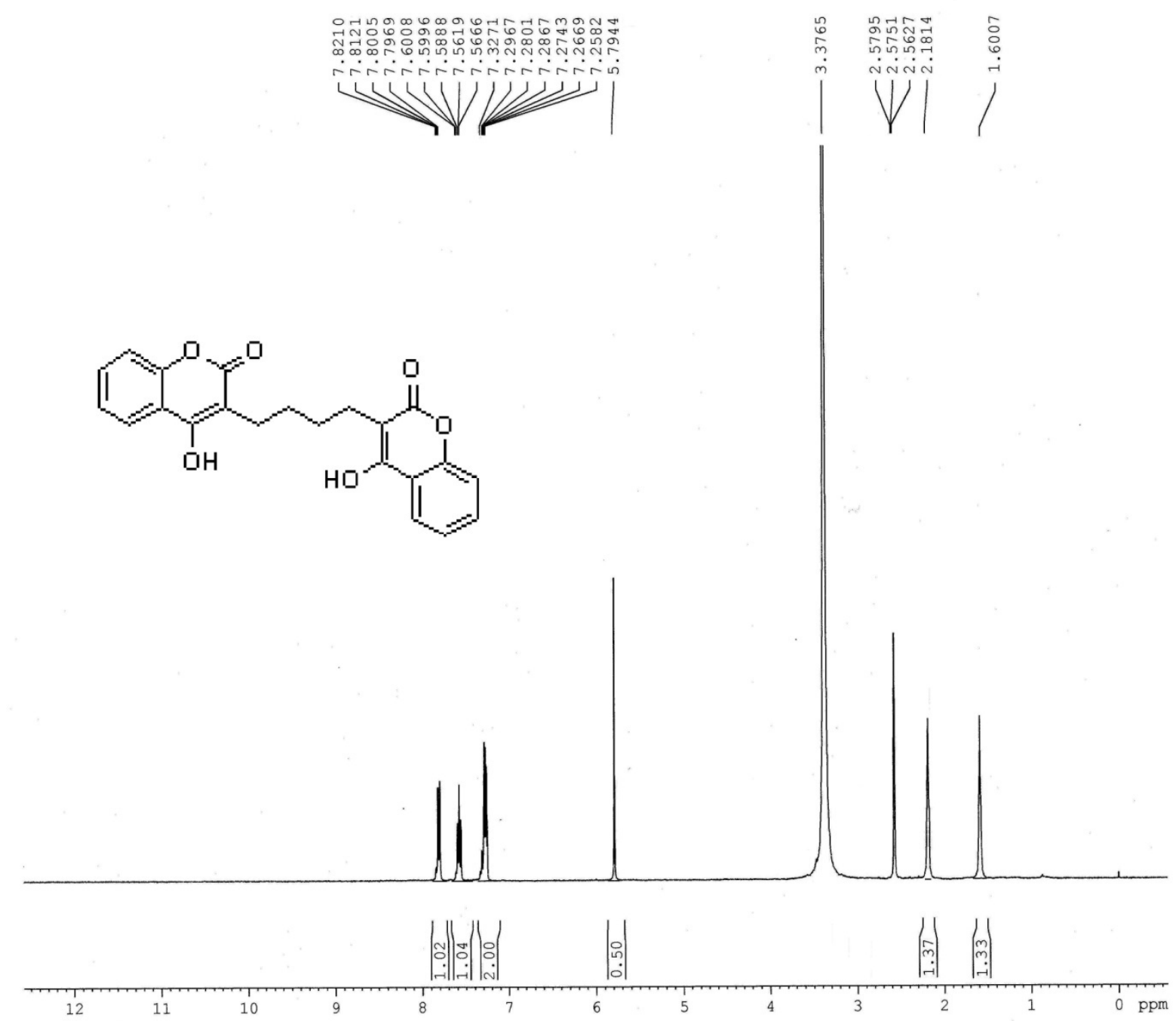

Figure-S2: ${ }^{1} \mathrm{H}$ NMR spectra of Impurity-B 


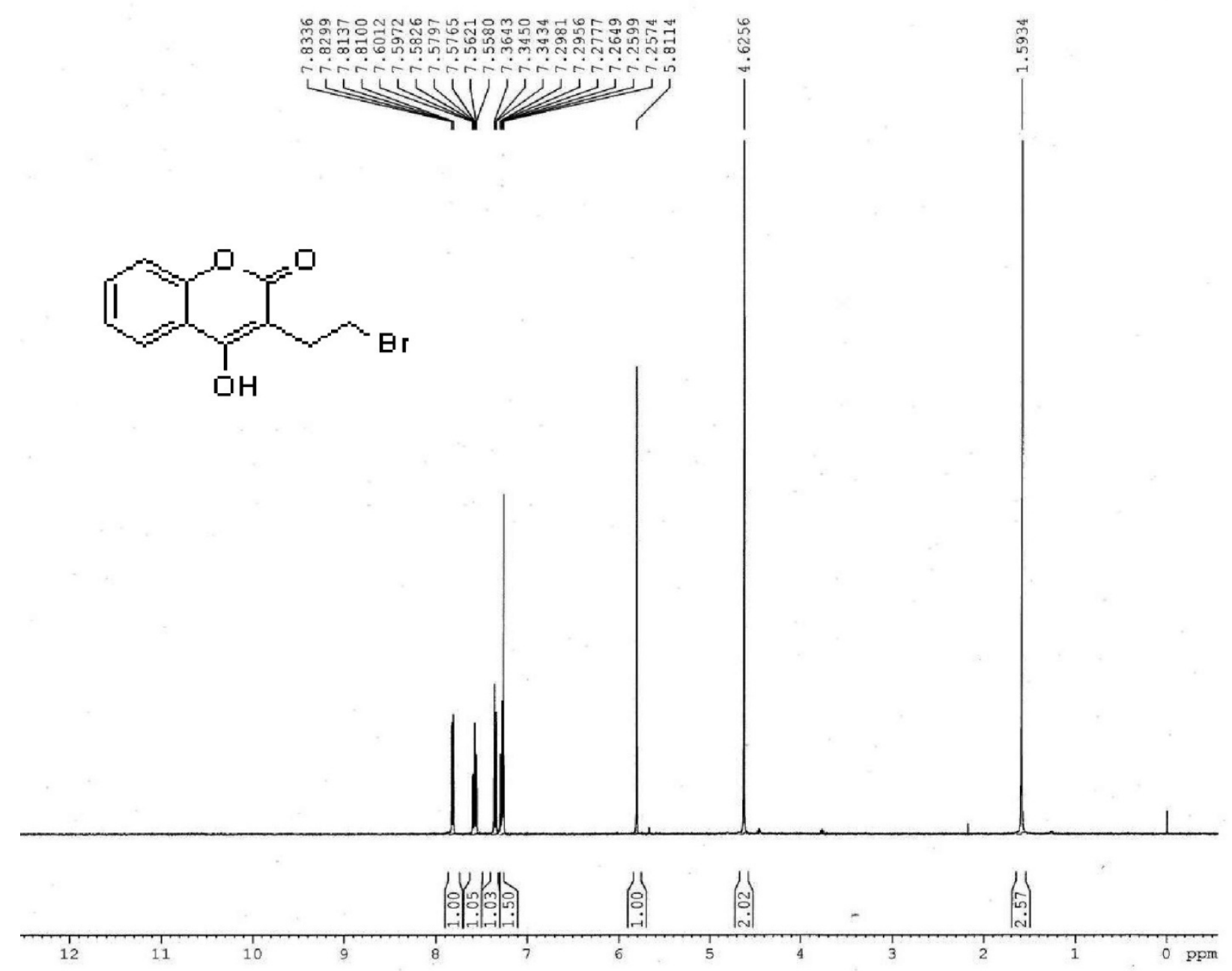

Figure-S3: ${ }^{1} \mathrm{H}$ NMR spectra of Compound 2 


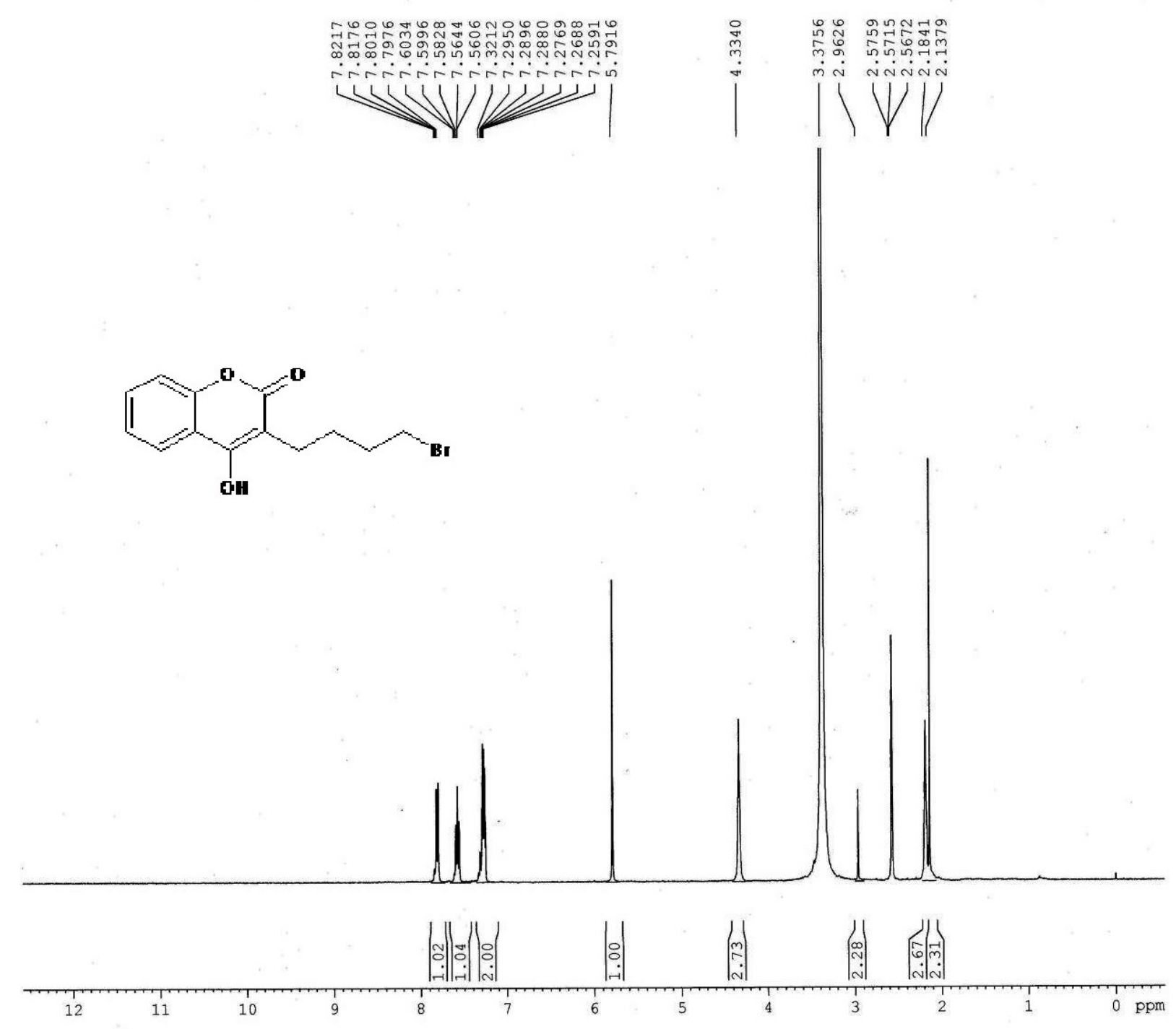

Figure-S4: ${ }^{1} \mathrm{H}$ NMR spectra of Compound 3 


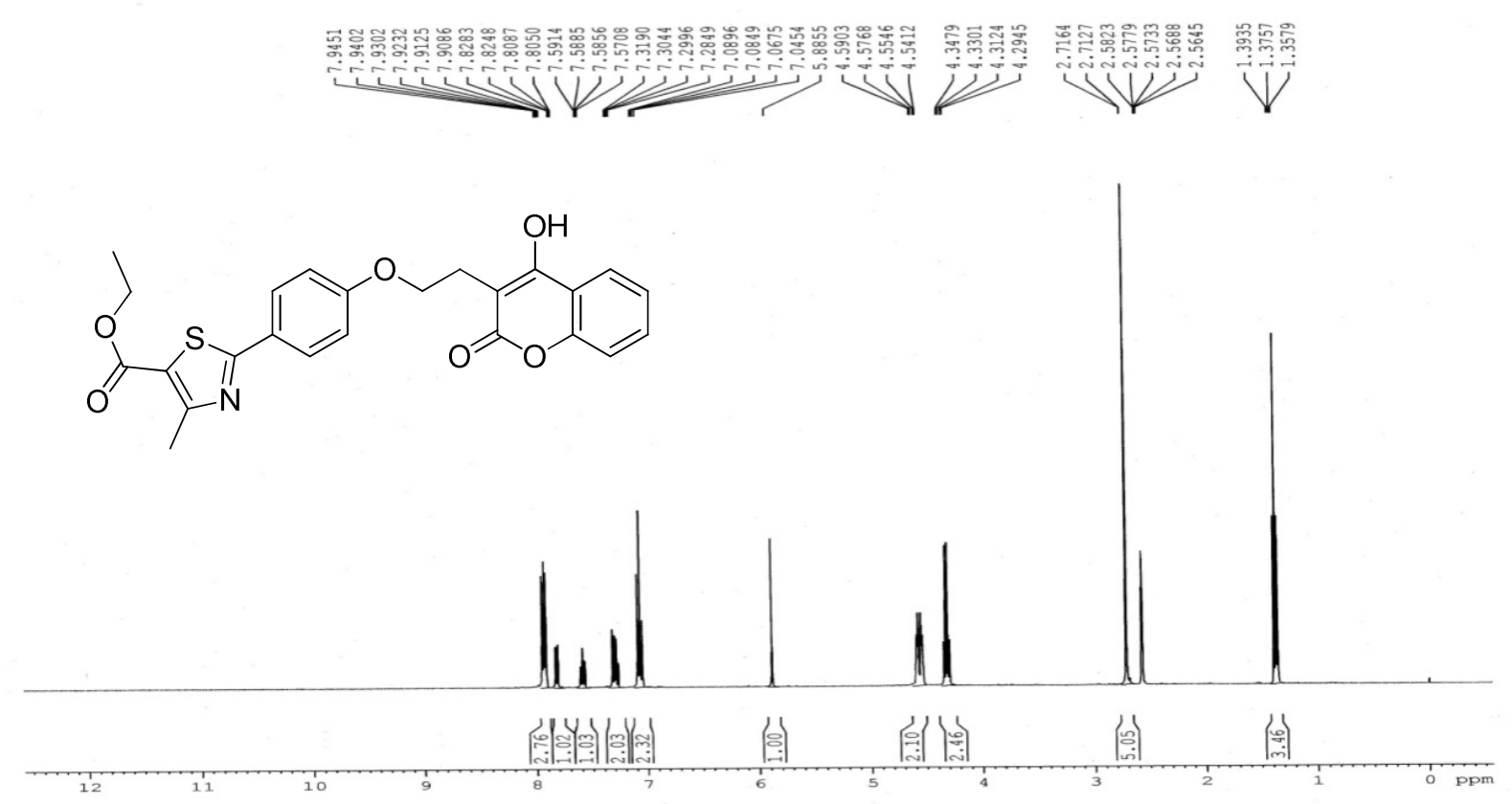

Figure-S5: ${ }^{1} \mathrm{H}$ NMR spectra of compound 4

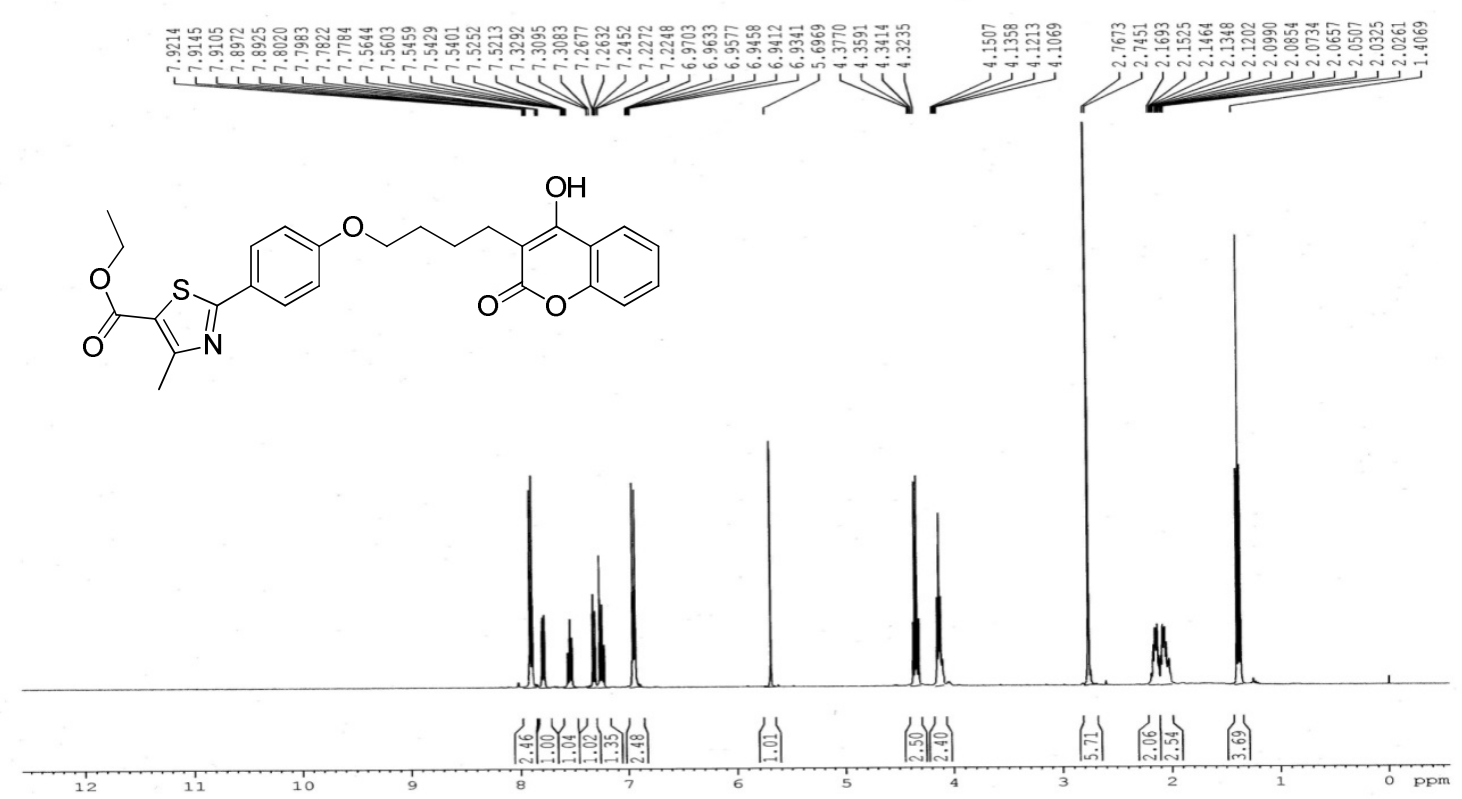

Figure-S6: ${ }^{1} \mathrm{H}$ NMR spectra of Compound 5 


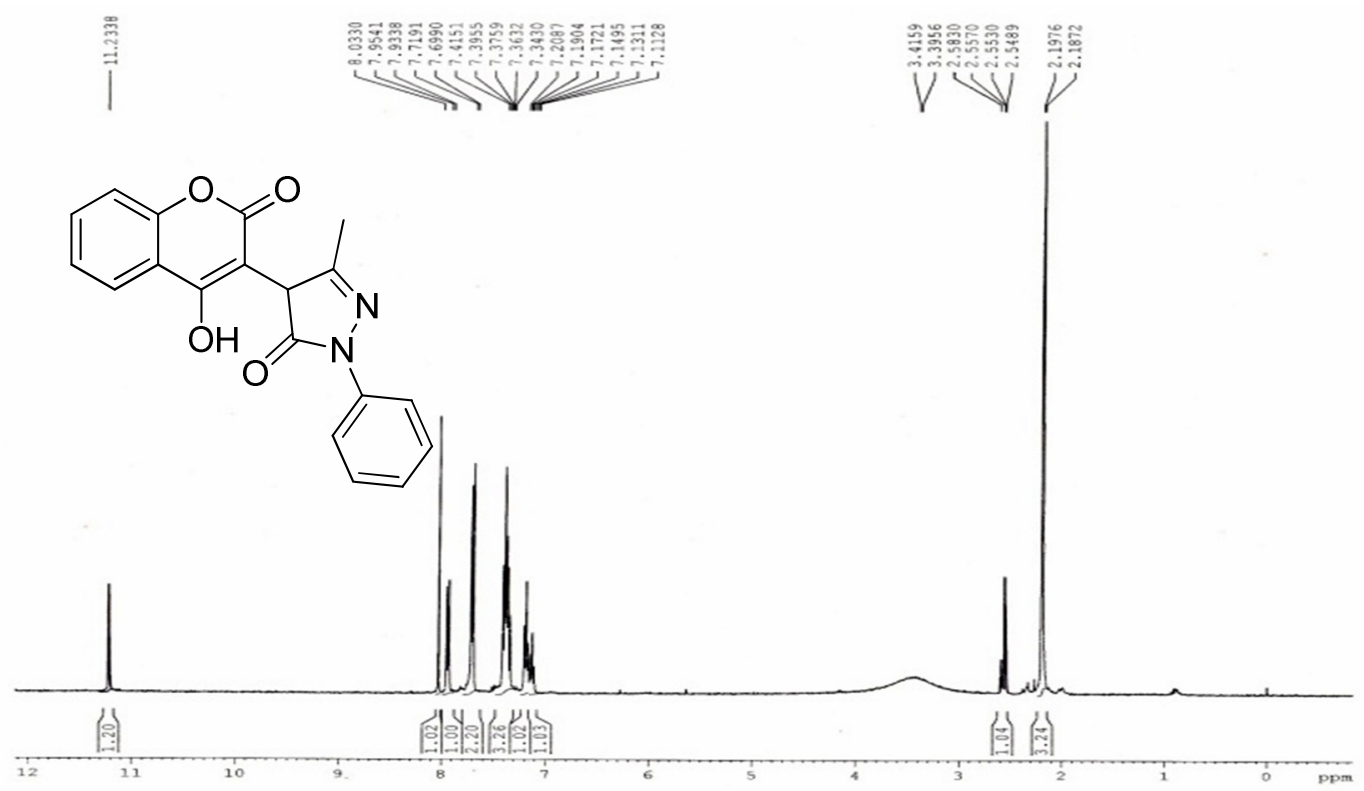

Figure-S7: ${ }^{1} \mathrm{H}$ NMR spectra of compound 6

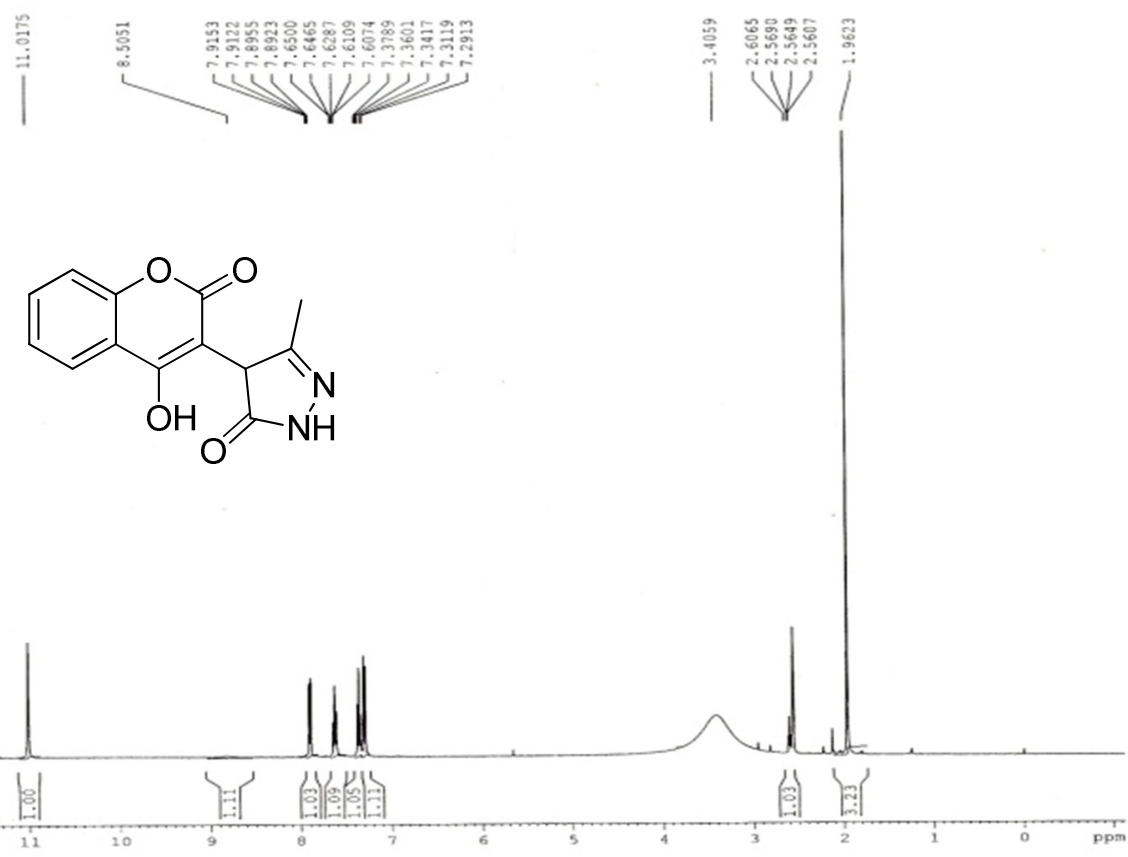

Figure-S8: ${ }^{1} \mathrm{H}$ NMR spectra of Compound 7 


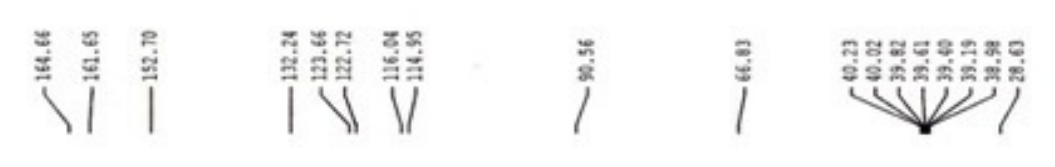<smiles>O=c1oc2ccccc2c(O)c1CCBr</smiles>

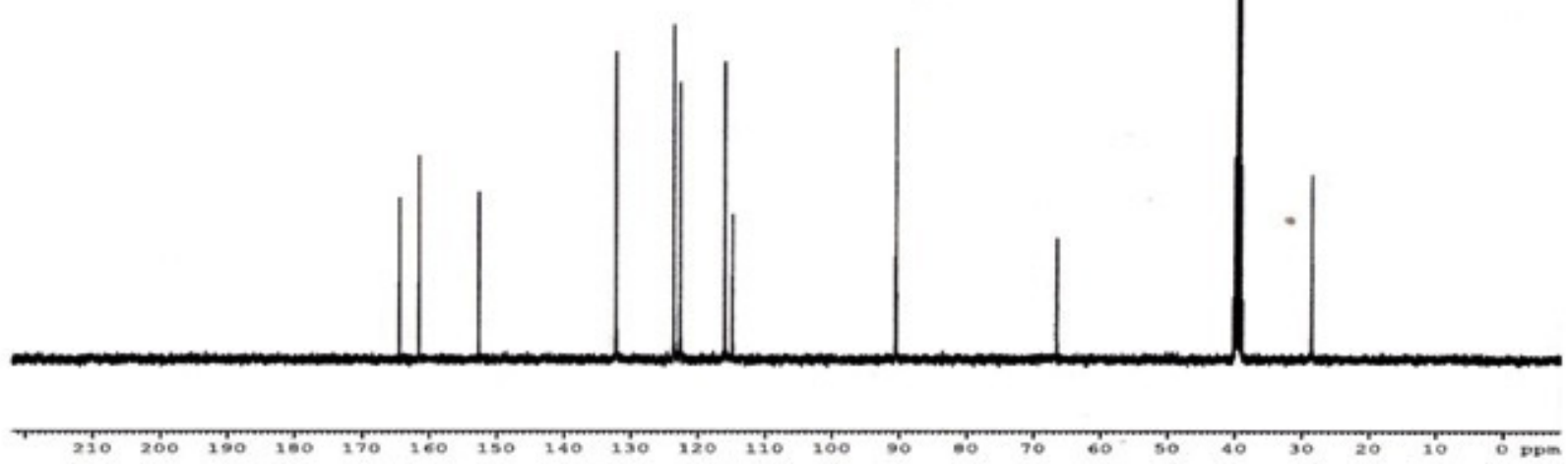

Figure-S9: ${ }^{13} \mathrm{C}$ NMR spectra of Compound 2
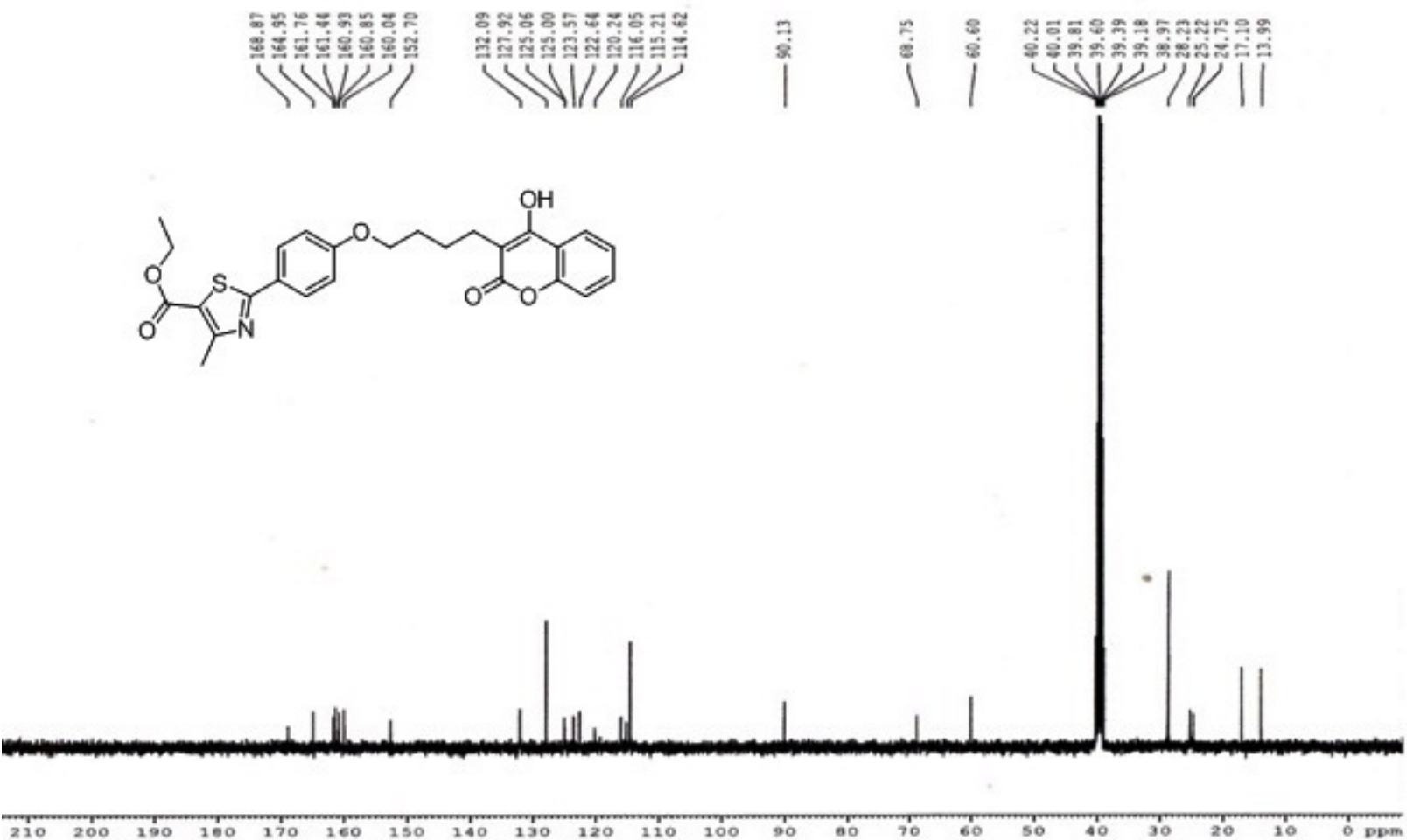

Figure-S10: ${ }^{13} \mathrm{C}$ NMR spectra of Compound 5 


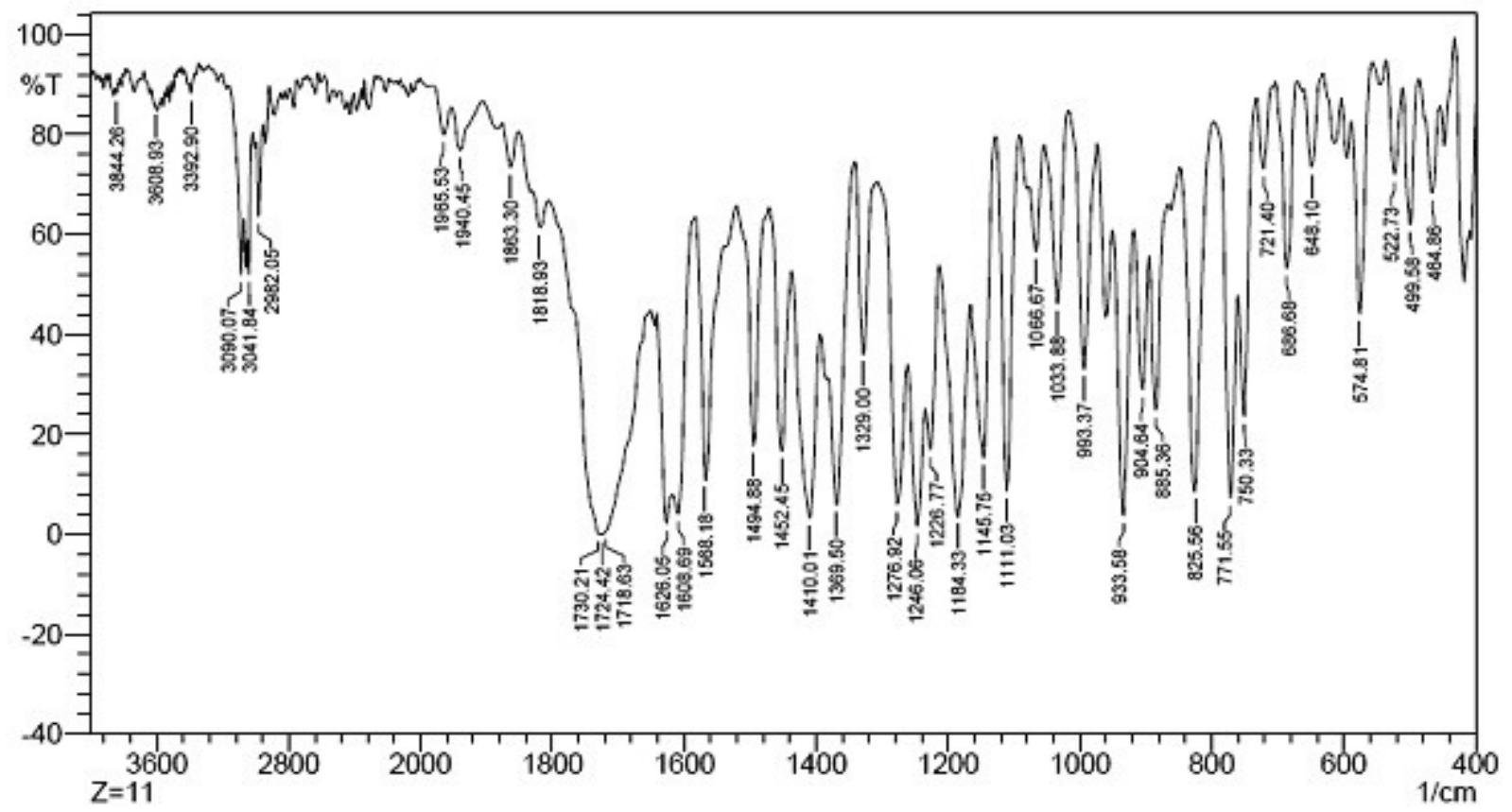

Figure-S11: IR spectra of Compound 2

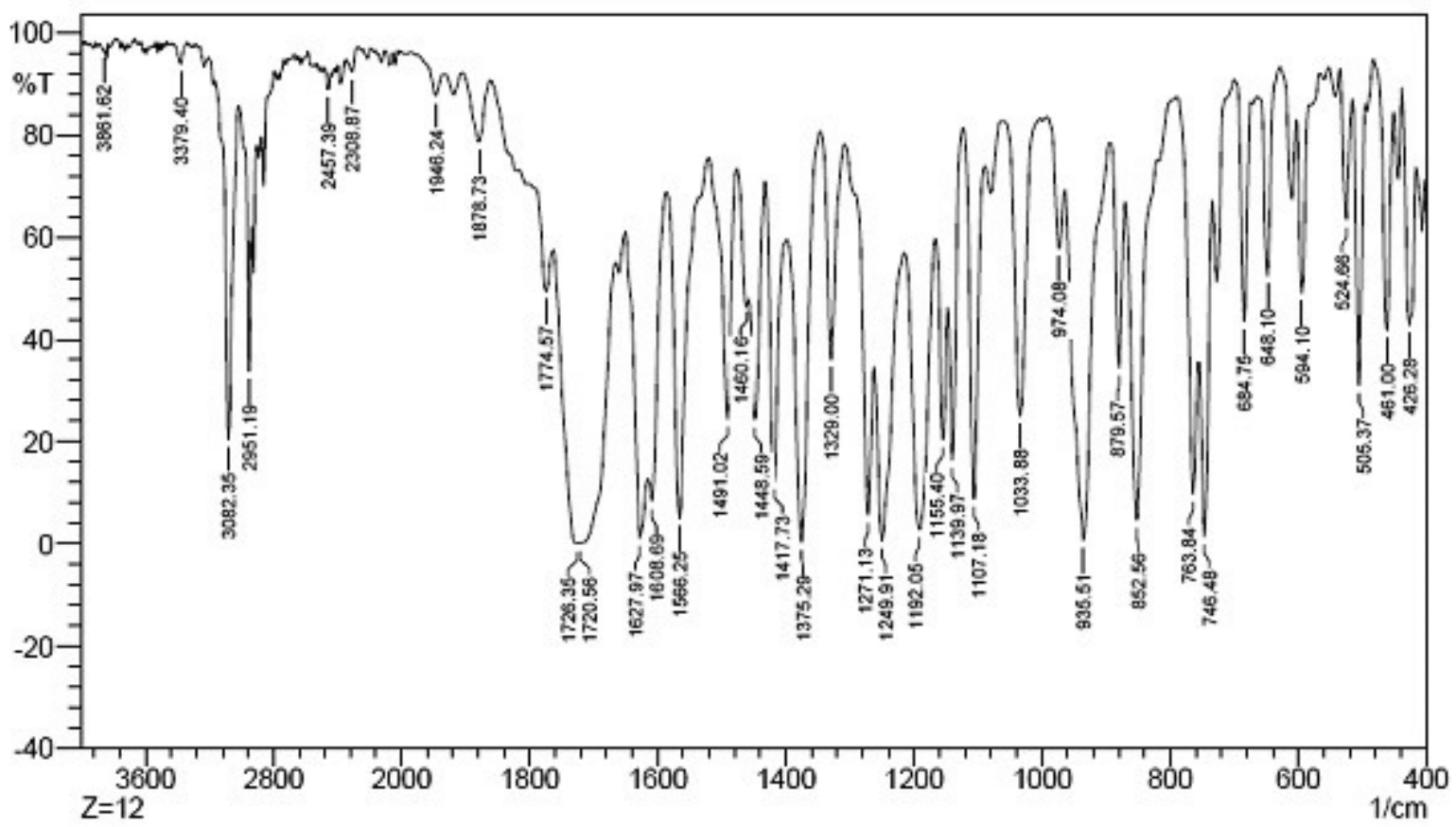

Figure-S12: IR spectra of Compound 3 


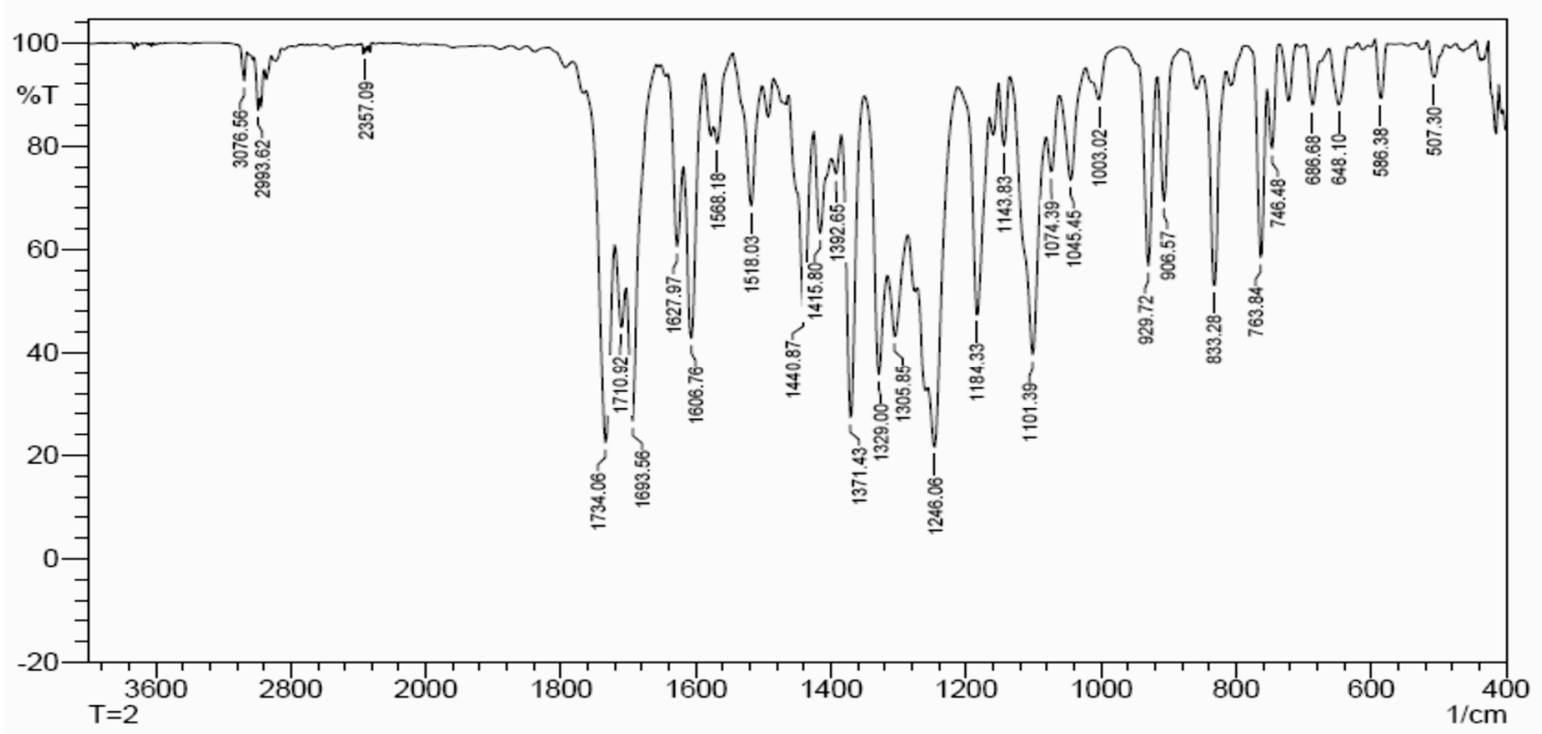

Figure-S13: IR spectra of compounds 4

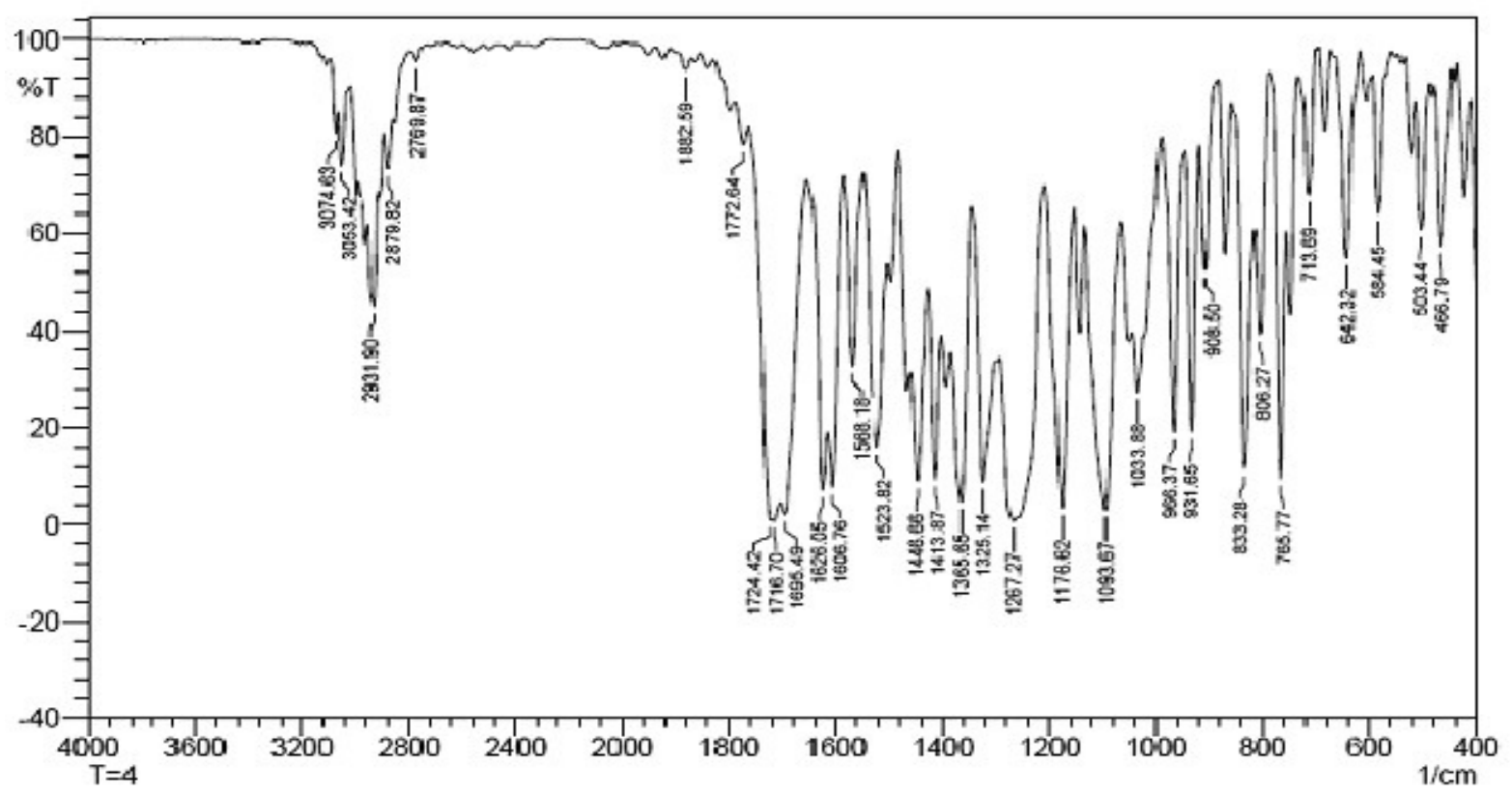

Figure-S14: IR spectra of Compound 5 


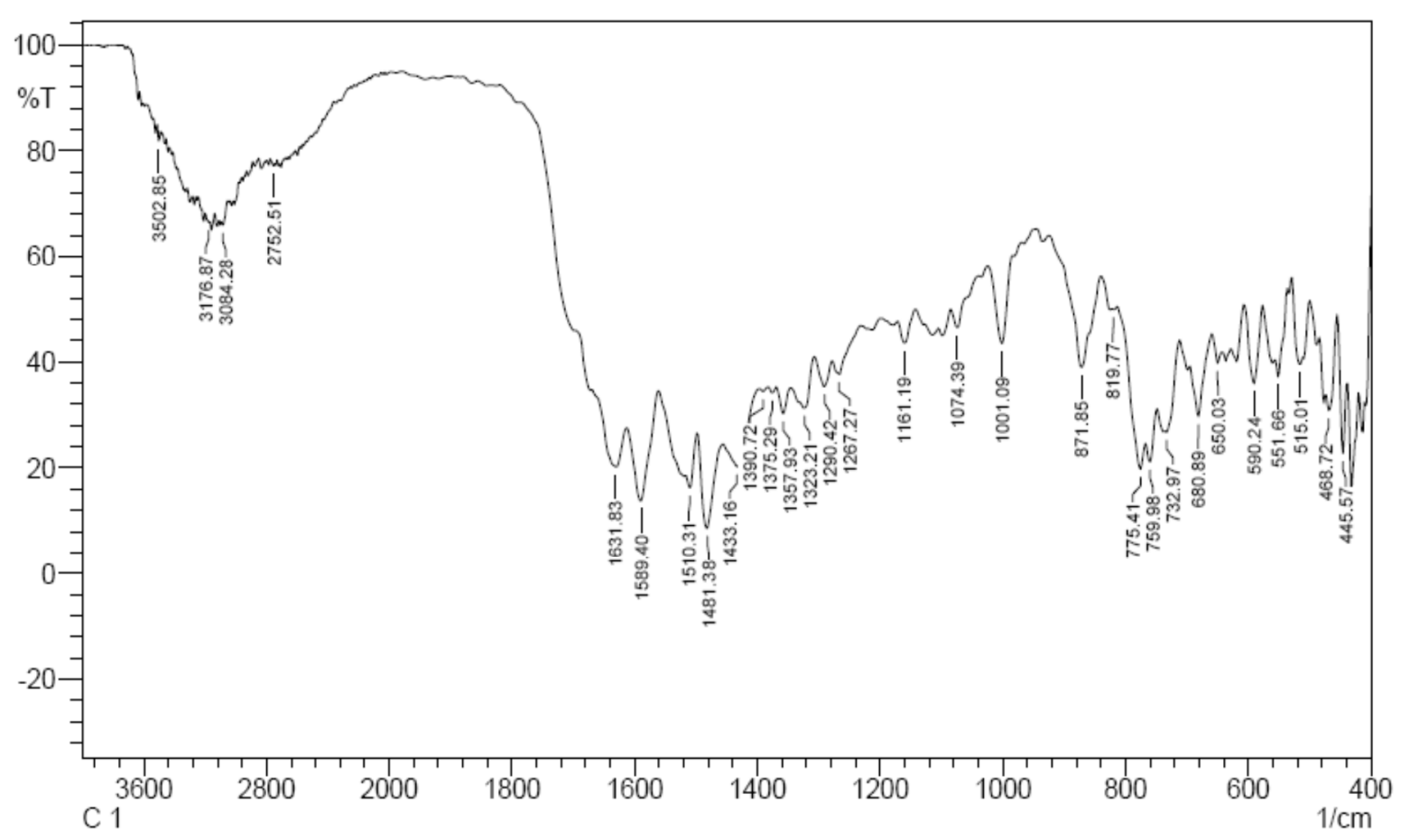

Figure-S15: IR spectra of Compound 6

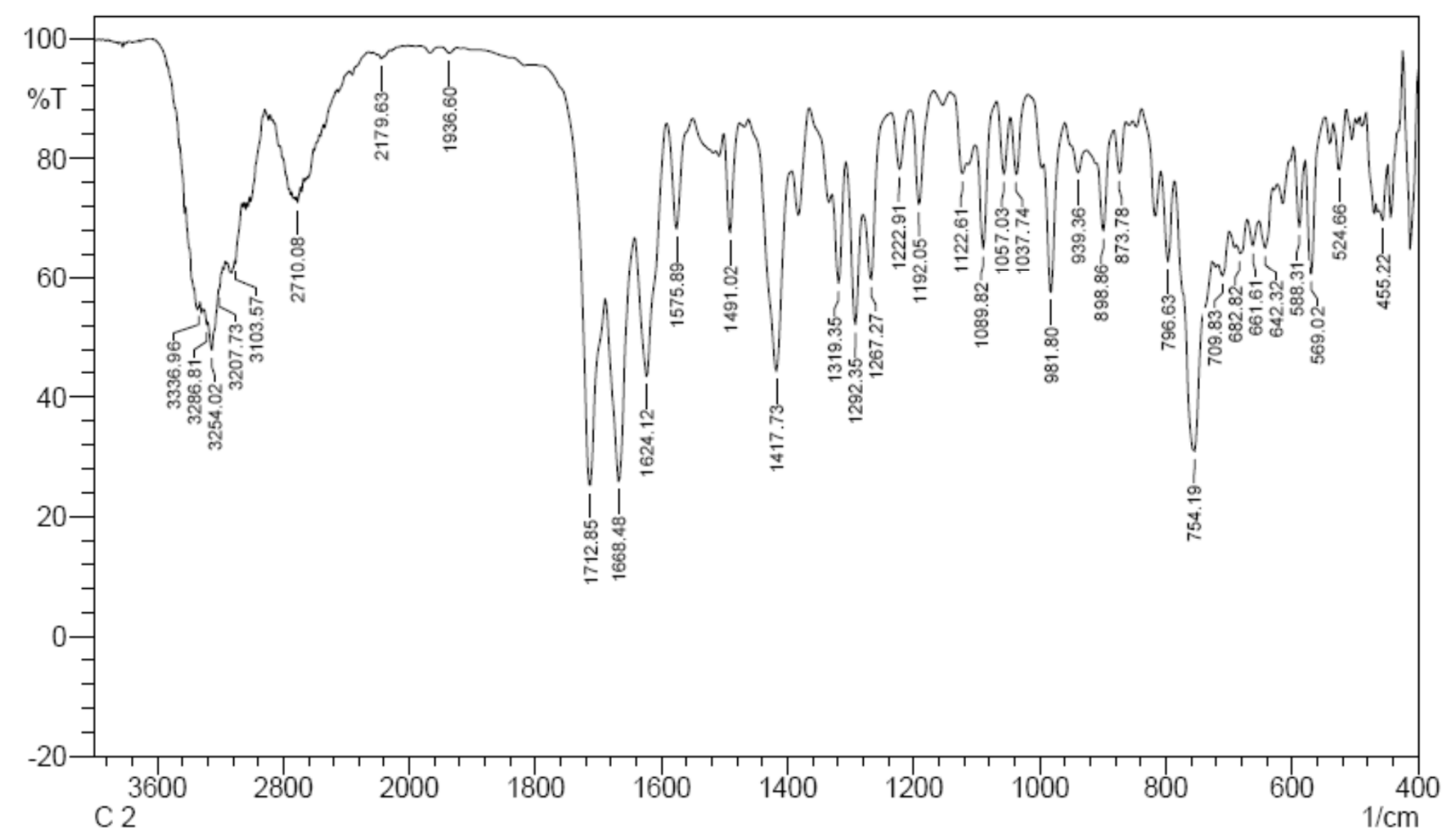

Figure-S16: IR spectra of Compound 7 


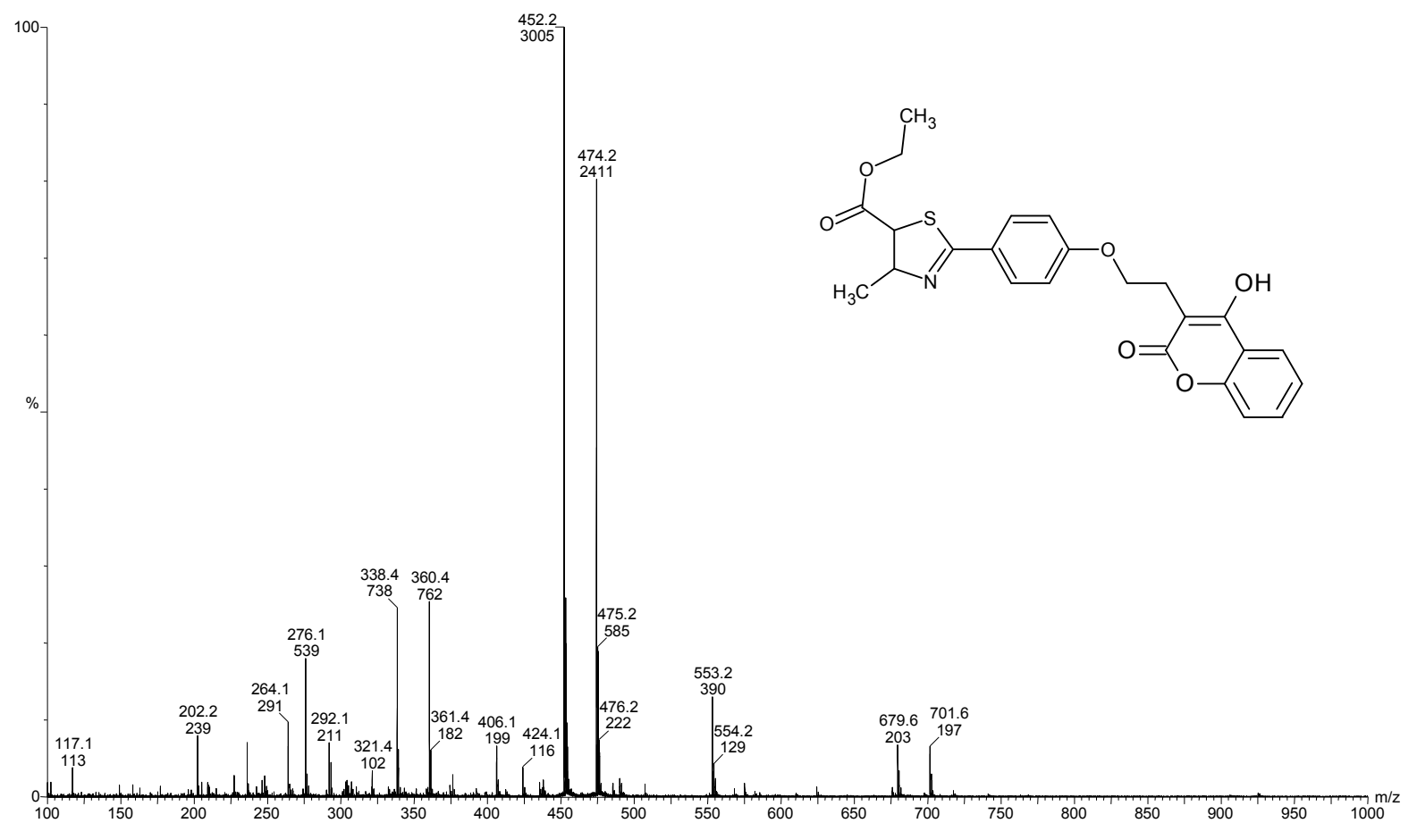

Figure-S17: Mass spectra of Compound 4

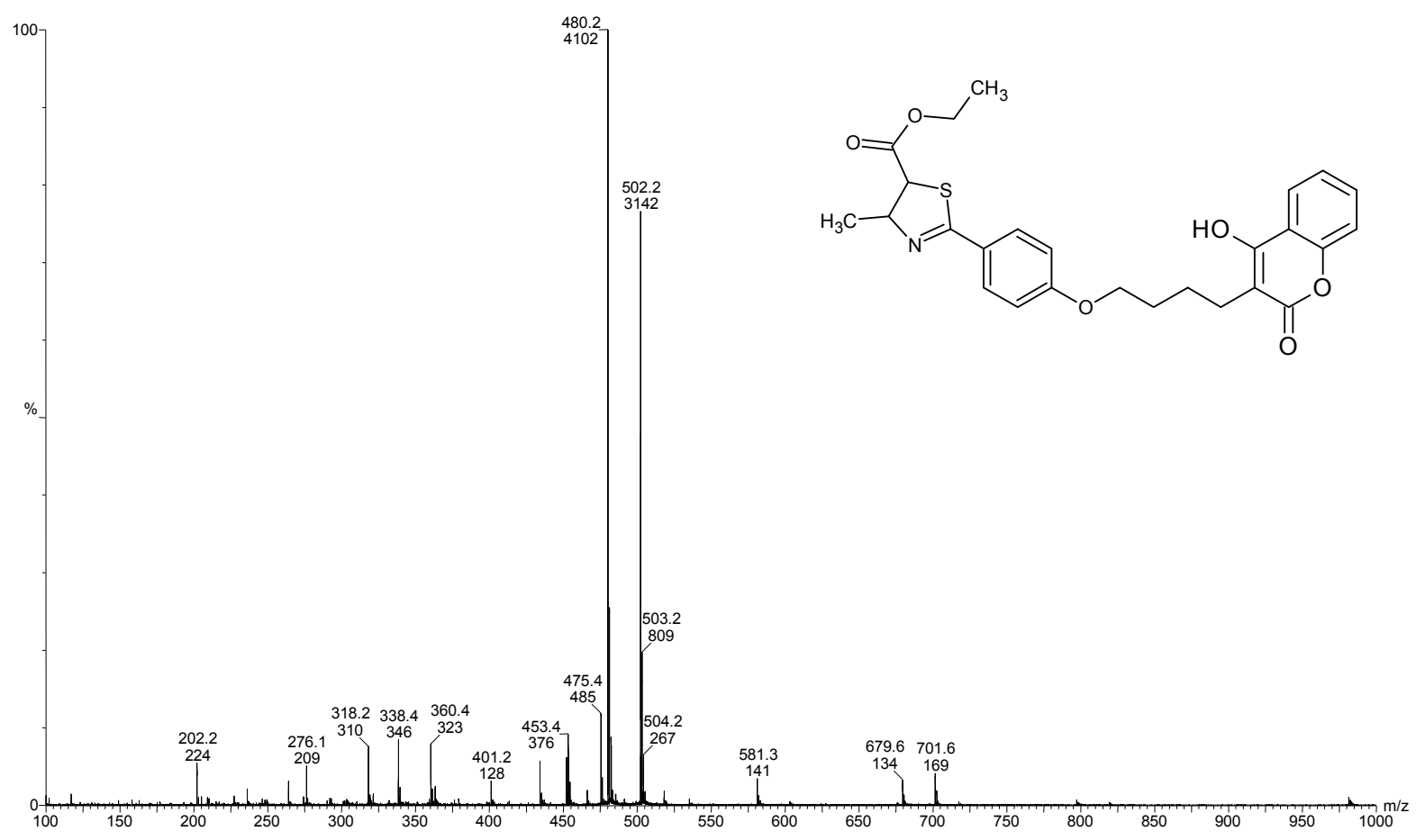

Figure-S18: Mass spectra of Compound 5 